\title{
HISTORIA MODERNA DE UNA LENGUA ORIGINARIA: EL JAQI ARU EN CHILE*
}

\section{MODERN HISTORY OF AN INDIGENOUS LANGUAGE: THE JAQI ARU IN CHILE}

\section{HANS GUNDERMANN}

Instituto de Investigaciones Arqueológicas y Museo R. P. J. Gustavo Le Paige, Universidad Católica del Norte. San Pedro de Atacama, Chile.

hgunder@ucn.cl

\section{JORGE IVÁN VERGARA}

Instituto de Investigaciones Antropológicas, Universidad de Antofagasta.

Antofagasta, Chile.

jorgeivan.vergara@uantof.cl

\section{ALBERTO DÍAZ ARAYA}

Universidad de Tarapacá. Arica, Chile.

albertodiaz@uta.cl

\section{RESUMEN}

La condición subordinada de la lengua aymara en Chile es explicada históricamente por un prolongado y persistente proceso de desplazamiento lingüístico en favor de la lengua nacional dominante. Se abordan los factores incidentes en dos niveles: el primero, la integración física, político-administrativa y educacional de áreas marginales de la cordillera andina, lo que se asocia a la formación moderna de la Región de Tarapacá a través de la acción del capital y el Estado durante los siglos XIX y XX; el segundo, la dinámica social interna de las comunidades aymaras y sus demandas culturales y educativas. El estado actual es el de un rápido retroceso del bilingüismo y un incremento correlativo del monolingüismo castellano, aun a pesar de la existencia de cambios tendientes a un mayor reconocimiento social de las lenguas y las culturas indígenas.

Palabras clave: Norte de Chile, lengua aymara, bilingüismo, desplazamiento lingüístico, subordinación idiomática. 


\section{ABSTRACT}

The subordinated state of the aymara language in Chile can be historically explained by an extended and sustained process of linguistical displacement in favor of the dominant national language. The relevant factors are placed at two different levels: on the one hand, the spatial, political and educational integration of peripherical areas of the Andean highlands, which is associated with the modern formation of the Tarapacá Region through the forces of capital and state during the XIX and XXth Centuries. On the other hand, the internal social dynamics of the aymara communities and their cultural and educational claims. The current situation shows a fast declination of bilingualism and the corresponding increase of Spanish monolingualism, in spite of the recent changes towards a wider social recognition of the indigenous cultures and languages.

Keywords: North of Chile, aymara language, bilingualism, linguistic displacement, idiomatic subordination.

Recibido: 05/01/2011. Aceptado: 10/03/2011

\section{INTRODUCCIÓN}

A bordaremos aquí la historia moderna del jaqi aru, la lengua de los ayma- ras, en relación con la conformación de las actuales regiones de Tarapacá y Arica-Parinacota en lo económico, lo administrativo y la acción estatal de corte desarrollista, particularmente desde la década de 1930 en adelante, aunque remitiéndonos también al siglo XIX, en el cual se inician cambios importantes en la situación lingüística de las comunidades aymarófonas del Norte Grande de Chile.

Esta historia es también social, en cuanto nos interesa atender a los cambios que experimenta el idioma aymara en su vigencia, distribución, vitalidad y prestigio frente a la lengua dominante, el español, entendiéndolos en relación con los procesos de transformación de la sociedad aymara: por ejemplo, la progresiva incorporación a los mercados de trabajo regionales, que requiere el conocimiento del castellano en tanto lengua general; y la expansión de la lectoescritura por parte de la escuela pública nacional, gracias a la cual el castellano alcanza, además, el estatus de lengua oficial y no sólo universal. Si dicha historia resulta prácticamente desconocida, sus resultados no. Gracias a diversos estudios, realizados en las décadas de 1980, 1990 y, sobre todo, del 2000, contamos con un diagnóstico de la situación sociolingüística actual del aymara en Chile, que constituye, por tanto, nuestro punto de partida problemático, al cual volveremos en la última parte del artículoº ${ }^{1}$.

${ }^{1}$ La distinción entre un análisis meramente cronológico de un fenómeno versus uno históricoestructural, que considera la situación actual y su contexto mayor como el punto de partida del proceso de investigación está tomada de Marx (1972 [1857-1858]: 20-30). 
¿Cómo estudiar la historia de una lengua si ésta pasa "por el lado" de los grandes acontecimientos regionales (la minería y los ciclos económicos regionales; la formación de la clase obrera y las ideas políticas que acompañan sus movimientos y luchas)? ¿Y que, por lo tanto -salvando excepciones- no concitó mayor interés $y$, en esa medida, difícilmente se registró lo que ocurría con ella? Una dificultad adicional lo representa el hecho de que -dejando de lado la experiencia colonial altoandina, que tuvo otras características- sólo desde hace una década y media se haya introducido la escritura de su lengua en medios escolares sin que haya habido una autorreflexión de los propios aymaras, particularmente de sus intelectuales y dirigentes, respecto de su uso en el contexto de su historia y cultura². Debemos así proceder de manera heterodoxa, recurriendo a recursos historiográficos poco convencionales, a datos fragmentarios y al apoyo de la etnografía, que permite también contextualizarlos socialmente. Junto con ello, se hará uso de los testimonios personales, las historias de vida y la historia oral.

En general, los estudios de largo plazo de las lenguas nativas regionales son considerablemente escasos, parciales; el tema es tocado sólo de manera limitada o representa una nota marginal. Y ello obedece tanto a las dificultades recién mencionadas para documentar su evolución, como a su carácter de tema limítrofe o de cruce entre varias disciplinas de las humanidades y las ciencias sociales.

\section{EL PANORAMA LINGÜÍSTICO REGIONAL DURANTE EL SIGLO XIX}

Al final de las revoluciones independentistas, las antiguas jurisdicciones coloniales desde las cuales se conformó la territorialidad de los estados nacionales en formación mostraban todavía una gran vitalidad de las lenguas indígenas. Como se recordará, el actual Norte Grande chileno formaba parte de dos naciones: Bolivia (la Región de Antofagasta) ${ }^{4}$ y a Perú (las regiones administrativas de Arica-Parinacota y Tarapacá) $)^{5}$ En su interior, el kunza de los atacameños estaba vigente y el aymara o jaqi aru se hablaba en toda la zona interior de Tarapacá y Arica; no siendo tampoco desconocido en algunos centros mineros regionales (como Huantajaya), a

${ }^{2}$ Con la salvedad de los trabajos de García (1997); Mamani, M. (1985) y Mamani, J.C. (2005) e iniciativas recientes, como la formación, al alero de la Corporación Nacional de Desarrollo Indígena (CONADI), de la Academia de la Lengua Aymara.

${ }^{3}$ Una excepción serían los trabajos de Durán y Ramos (1986, 1987a y 1987b) referidos a la adquisición del castellano y a la formación de situaciones regionales de bilingüismo entre los mapuches del centro sur de Chile. Con todo, puede considerárseles como apertura de un tema de estudio más que su resolución. Para antecedentes históricos generales de las lenguas indígenas de Chile véase Salas (1996) y Sánchez (1993-1994).

${ }^{4}$ Hasta su anexión por Chile en 1879 se le conoció como Provincia o Departamento Litoral o Lamar y su área interior indígena como Provincia de Atacama (Cajías, 1975).

${ }^{5}$ Departamentos de Tarapacá y área meridional del de Tacna, respectivamente. 
juzgar por la presencia de trabajadores indígenas (Villalobos, 1979). Pero cambios de gran envergadura ya se habían llevado a efecto para algunas lenguas minoritarias, como la de los indígenas changos en el litoral de Antofagasta que, durante la primera mitad del siglo XIX, ya eran monolingües del castellano (Bollaert, 1860: 155-156). Asimismo, las presiones para el abandono del kunza eran ya ostensibles en Atacama (Hidalgo, 1984: 157-184) ${ }^{6}$.

William Bollaert, viajero, explorador, químico y etnólogo inglés que permaneció algunos años en la provincia de Tarapacá a partir de 1825, y en una segunda estadía, algunas décadas más tarde, desde 1854 (Bermúdez, 1975: 313-318), señala con énfasis: "The Indians of the province of Tarapacá are Aymarás, and speak that language" (Bollaert, 1860:163)7. Los principales poblados indígenas que visitó durante sus recorridos por la zona fueron Mamiña, Camiña, Tarapacá y Chiapa en la precordillera andina, e Isluga en el altiplano. El grado de monolingüismo presente en la región de residencia tradicional aymara puede colegirse de su comentario sobre una localidad andina: "Mamiña is a large Indian town, and where the Aymará only is spoken" (Ibíd: 165)․ Tal parece, entonces, que la lengua nativa se distribuía por todo el espacio indígena regional surgido de la reorganización colonial llevada a efecto a finales del siglo XVI e inicios del XVII. Y, además, se encontraba firmemente arraigada, al punto que en un poblado como Mamiña, accesible sin mayor dificultad desde Pica y Tarapacá (sitios donde asentaron españoles, criollos, mestizos, además de algunos esclavos) y aledaño a los cantones salitreros en formación, en la primera mitad del siglo XIX se tenía al aymara como única variedad lingüística para la comunicación?.

Más al sur, todavía a mediados del siglo XIX podía escucharse el kunza en algunas aldeas atacameñas del salar de Atacama. El sabio Rodulfo Amando Phillipi indica sobre el particular: "Es muy singular que los Atacameños hablan un idioma

${ }^{6}$ La lengua quechua ha ejercido influencia sobre el español de los países andinos y también del de Chile (Lenz, 1905-1910). Pero no será sino hasta la afluencia de trabajadores cochabambinos hablantes del quechua a las faenas salitreras en las postrimerías del siglo XIX, o de los trabajadores que por la misma época empezaban a afluir desde el sur de Potosí hacia las faenas mineras de altura (azufre, bórax, cobre) en la provincia de El Loa, que esta lengua estará presente en las regiones septentrionales del país. En el primer caso, los hablantes retornaron a Bolivia o se fundieron con la masa trabajadora minera (González, S., 2002a [1990]). En el segundo, la permanencia de algunas familias en villorrios rurales y su tardía incorporación a la ciudad de Calama explican la persistencia de una conciencia de grupo indígena y la vigencia parcial de su lengua (Gundermann, 2007: 63-87). Emigrantes peruanos a Santiago de Chile son, a veces por su origen geográfico en regiones de la sierra peruana, hablantes hoy de alguna variante de esta importante lengua amerindia.

7 "Los indígenas de la Provincia de Tarapacá son aymaras y hablan esta lengua" (Bollaert, 1975 [1860]: 474).

8 "Mamiña es un gran pueblo indígena donde sólo se habla el aymara" (Bollaert, 1975 [1860]: 476).

${ }^{9}$ Anotemos que esta localidad andina sigue siendo importante, pero hace mucho tiempo ya que sus habitantes, descendientes de los pobladores que Bollaert visitara hace más de un siglo y medio, son monolingües del castellano. 
particular, enteramente distinto del quichua y del aymará como del chileno... El idioma atacameño es limitado a una población de tres a cuatro mil almas, hablándose únicamente en los lugares: S. Pedro de Atacama, Toconado, Soncor, Socaire, Peine, Antofagasta [de la Sierra], y unos pequeños lugarcitos del cantón Chiuchiu" (Phillippi, 1860: 56) (destacado en el original). Ya no se trata, sin embargo, de la lengua que todos o casi todos hablan con exclusividad, como por esa misma época ocurría en la aymara provincia de Tarapacá y en la de Arica y Tacna, más al norte. El autor añade: "Hubo un tiempo en que el idioma atacameño se hablaba también en Chiuchiu y Calama, pero actualmente lo ha subrogado el español en estos pueblos, y sólo personas muy anzianas entienden todavía la lengua de sus padres" (Ibíd: 56).

Lenguas originarias extendidas por amplias regiones, y con una profusa base de hablantes, permanecen notoriamente vigentes y vitales. Ése fue el caso del aymara durante la primera mitad del siglo XIX. Se debe recordar, también, que importantes áreas contiguas hacia el oriente (Oruro y el departamento de la Paz) en el altiplano boliviano, y hacia el norte (Moquegua, Puno) en el sur de Perú, sostuvieron un estado equivalente de vitalidad del jaqi aru. Son regiones que han tenido un papel importante en la suerte ulterior de la lengua en Tarapacá y Arica. Lenguas circunscritas a zonas pequeñas y con contingentes de población reducidos, como el kunza de los atacameños, disponían, por su propia estrechez, de una situación de base poco propicia para resistir las presiones externas que ya se hacían notar, lo que repercutió en el retroceso de su lengua. A su vez, idiomas de pequeños grupos especializados, como en el caso de los changos de la costa, habían sido desplazados por el castellano, quienes, para fines de intercambio, manejarían algo de las lenguas andinas con las que guardaban contacto (Bollaert, 1860: 155).

Arica y, sobre todo, Tarapacá fueron en la segunda mitad del siglo XIX y primeras décadas del XX un espacio multicultural y multilingüe con presencia de lenguas amerindias: el quechua de los obreros cochabambinos, el aymara de los indígenas de la zona y de las regiones bolivianas vecinas; europeas: inglés, francés, alemán, croata y griego de grupos y redes de emigrantes y agentes económicos de la industria, el comercio y los servicios; y asiáticas: el idioma de los trabajadores chinos que permanecieron en la zona (González, S. 2009). La lengua oficial y dominante de las relaciones económicas y sociales en la región ya era, obviamente, el castellano. Las lenguas minoritarias no fueron necesariamente idiomas subordinados, como las europeas, en especial el inglés, francés y alemán cuya comunidad de hablantes se limitó a los de esos orígenes nacionales, pero gozando de un estatus y prestigio más alto que las demás ${ }^{10}$. Incluso, se da el caso de una lengua de bajo

\footnotetext{
${ }^{10}$ Por tratarse de lenguas de las relaciones económicas con los países centrales y por fomentarse a través de instituciones escolares o clubes y agrupaciones sociales. Al respecto, son muy valiosos los comentarios del viajero inglés Francis J. G. Maitland, quien visitó Iquique a inicios del siglo XX, llamándolo "el pueblo más inglés de Chile" (cit. por Bravo-Elizondo y González, 1994: 120). Observó
} 
prestigio como el cantonés, pero persistente a través de la lealtad cultural y lingüística de las familias de origen chino. La peor posición relativa la ocuparon las lenguas amerindias que arrastraban una condición de minorización ${ }^{11}$ ya establecida y la posición social subalterna de sus hablantes, los "indios".

\section{PROCESOS REGIONALES Y LENGUAS INDÍGENAS: AUGE SALITRERO Y ANEXIÓN DE TARAPACÁ; CIRCUITO MERCANTIL Y OCUPACIÓN DE ARICA Y TACNA}

La segunda mitad del siglo trae consigo un vasto proceso de reconfiguración económica, política y sociocultural regional en Tarapacá, Arica y Antofagasta. No podemos detenernos en sus detalles, conformándonos aquí con indicar los aspectos más salientes. A destacar es que propiamente se organizan las regiones. La de Arica y Tacna en función de mantener y expandir las actividades portuarias y el transporte de bienes hacia y desde Bolivia, lo que da forma a un dinámico circuito mercantil. La de Tarapacá, una provincia con vocación minera desde tiempos coloniales (Villalobos, 1979; Gavira, 2005), prolonga esta orientación hacia la extracción de guano (wanu) desde depósitos costeros y, sobre todo, a la explotación de depósitos de caliche, la elaboración de salitres y yodo y su exportación a ultramar (Bermúdez, 1963, 1981). Todo lo anterior supuso el desarrollo de infraestructura de transporte ${ }^{12}$, habilitación de puertos y caletas, ampliación de los ya existentes y desarrollo urbano (crecimiento de Arica, Tacna, Iquique y Pisagua, campany towns ${ }^{13}$. La escala y profundidad de estos cambios se acentuaron con la anexión de Tarapacá a Chile, que coincide con el medio siglo de auge de la industria del salitre. Pero también, con la especial condición política de Arica y Tacna hasta 1929 y, en relación con ello, la construcción y puesta en funciones

que en la ciudad se hablaban "tanto el español como el inglés, y es el idioma extranjero que más se enseña en las escuelas. Lo siguen el francés y el alemán. El lenguaje es tan conocido y entendido que muchos comerciantes exhiben sus avisos sin darse el trabajo de traducirlos al castellano" (Ibíd: 120).

${ }^{11}$ Entendemos por minorización un proceso histórico según el cual una lengua (o un dialecto), por relación a otra u otras lenguas o variantes en una región o en un Estado, no ha llegado a adquirir el estatus de lengua oficial, no es empleada ni su uso es autorizado para fines institucionales o burocráticos, no constituye o lo es en una medida muy limitada un medio de enseñanza, no ha sido objeto de un proceso de normalización o estandarización, su reproducción es básicamente oral y su adquisición se lleva a efecto esencialmente en el medio familiar, el acceso a y su empleo en los medios de comunicación de masas es inexistente o limitado, su valor como capital cultural para quien la aprende es bajo y sus funciones comunicativas son vernaculares y emblemáticas (Kasbarian, 1997: 185-188). El perfil corresponde bastante bien con la posición de las lenguas amerindias u originarias en Chile y, particularmente, del aymara respecto de la promoción y el sustento oficial del castellano.

${ }^{12}$ Caminos de carreta, primero, y ferrocarriles para conectar las faenas mineras con puertos o para el traslado a gran escala de mercaderías, después.

${ }^{13}$ Mayores detalles pueden encontrarse en Thompson y Angerstein (1997); Villalobos (1979); González, S. (2002a [1990] y Bermúdez (1963 y 1981). 
del ferrocarril Arica-La Paz (cumpliendo compromisos con Bolivia), inversiones en edificios y servicios públicos, acción política de "chilenización" en los centros urbanos y la región interior, etc. (Espinoza, 1903; González, S., 2002a [1990]).

Una consecuencia de los cambios que acabamos de reseñar es demográfica. Entre la segunda mitad del siglo XIX y las postrimerías del mismo, los indígenas pasan de ser mayorías regionales ${ }^{14}$ a francas minorías. Es una condición que se fue pronunciando durante el siglo XX, tendencia que se mantiene en la actualidad: la minoría aymara, según el último censo, reúne apenas un 11,5\% de la población de las dos regiones Tarapacá y Arica - Parinacota (INE, 2003: 23-24). Con la industria extractiva, la construcción de ferrocarriles, la habilitación portuaria y la expansión urbana, la afluencia de trabajadores peruanos, bolivianos y, sobre todo, chilenos, sobrepasó rápidamente a los indígenas de la región. Por lo general monolingües del español, el quechua y no el aymara fue la lengua indígena poseída por algunos de estos recién llegados (caso de los trabajadores cochabambinos que afluían a Tarapacá, como se indicó en nota 4) (González, S., 2002a: 241-280).

Otra resultante es que una parte de los aymaras se incorpora a los contingentes de trabajadores de la minería y los puertos, en tanto que el grupo más numeroso se mantuvo vinculado con la agricultura andina. Algo análogo, aunque en una escala menor, tuvo lugar en el interior de Arica y Tacna con la arriería, el transporte de carga en carretas, los trabajos ferrocarrileros y la minería de altura (azufre en Tacora, por ejemplo) que se expandió con la puesta en funciones del ferrocarril de Arica a la Paz en 1913 (Keller, 1946: 236 y 293). Aquí y allá, como tercer asunto, las actividades agropecuarias se especializan en la producción de forrajes para animales de trabajo, en hortalizas y frutas para el consumo humano en los campamentos mineros y centros urbanos, y en la extracción de combustibles vegetales (llareta, queñua) para campamentos mineros de altura y centros urbanos como Arica. Son cuestiones que forman parte de un más amplio proceso de integración indígena a la región a través del mercado de trabajo asalariado, el de productos campesinos y el de bienes de consumo humano. La alta cordillera andina y la altiplanicie boliviana aledaña tampoco permanecieron aisladas debido al comercio de carne y productos de Bolivia como la hoja de coca, activamente consumida en los trabajos mineros.

La lengua de uso general para esta más amplia y profunda integración econó-

\footnotetext{
${ }^{14}$ Para la situación de la primera mitad del siglo XIX, Gootenberg revisa y corrige los porcentajes de Kubler (1952), estipulando para Tarapacá 5.797 indígenas, lo que corresponde a un 63,2\% de la población de la provincia en 1840, porcentaje algo inferior al de $1793-1795$, con un $68,2 \%$ del total. Arica y Tacna, por su parte, en 1827 tendría 10.545 indígenas que representan un 52,2\% de la población, porcentaje notoriamente inferior al de 1793-1795, cuando asciende a un $68,5 \%$ (Gootenberg, 1991:138), cuestión quizá atribuible a una activación del circuito mercantil AricaTacna-La Paz.
} 
mica a la región fue el castellano ${ }^{15}$. Pero la llegada del español a la zona andina no es sólo producto de su aprendizaje por un sector de aymaras que lo requirieron a medida que se intensifican sus vínculos con una economía regional en rápida expansión. En pueblos interiores como Tarapacá (antigua capital de la provincia homónima, reemplazada por Iquique), Pica-Matilla o el valle de Azapa, la presencia de criollos castellano-hablantes data de tiempos coloniales. En estos y otros lugares, como Camiña, Codpa, Lluta, Sibaya o Belén, el interés por tierras para el cultivo de forrajes y productos agrícolas de consumo humano estimuló la llegada de personas desde otros lugares del sur peruano, presionando ahora desde dentro la ampliación de la base de hablantes del español ${ }^{16}$.

Las circunstancias políticas regionales aportaron lo suyo. La anexión de Tarapacá y la ocupación de Tacna y Arica acarreó una nueva organización políticoadministrativa del territorio y la presencia más o menos continua e intensa, según los casos y momentos, de funcionarios (subdelegados, jueces e inspectores de distrito, estos últimos por lo general vecinos de los pueblos, hablantes del castellano y alfabetizados) y policías en las zonas andinas y las fronteras con Perú y Bolivia. Ambos sirvieron como nexos entre las localidades andinas y las oficinas públicas y autoridades provinciales y regionales con sede en Iquique, Pisagua, Arica y Tacna. La lengua de estas relaciones y de la documentación generada fue el castellano, salvo quizá en sitios como las comunidades de pastores en la zona de frontera, por esa época todavía principalmente monolingües, para quienes se requirió de bilingües escogidos entre sus "paisanos" ${ }^{17}$.

Hubo escuelas parroquiales y públicas de primeras letras funcionando en cabeceras de curato y pueblos centrales (como Tarapacá, por ejemplo) hasta la anexión

${ }^{15}$ Para el testimonio de un aymara que llegó a trabajar a las oficinas salitreras de la actual provincia de Iquique en calidad de monolingüe del aymara o bilingüe apenas incipiente del castellano, confróntese González (2002b:34). El mismo testimonio sirve al propósito de especificar que la tendencia de los obreros indígenas a agruparse entre ellos todavía posibilitó el uso del jaqi aru en algunos espacios laborales, aunque acompañado de un progresivo declive en el prestigio de la lengua (Idem: 32-34).

${ }^{16}$ Ello fue posible luego de que el régimen de tierras indígenas se liberalizara, en especial después que se aboliera en 1854 el régimen de tributación conocido como "contribución indigenal". Este suponía exacción fiscal, pero también protección de las autoridades ante las presiones de enajenación por particulares, barreras legales y administrativas que desde mediados del siglo XIX no operaron o fueron sobrepasadas (para la zona en estudio, confróntese: Gundermann, 2001).

${ }^{17}$ En 1862 doña María Callpa, oriunda de Usmagama (pequeña localidad ubicada en la precordillera alta de la Quebrada de Tarapacá) en un juicio por posesión de tierras ventilado ante el juez de Paz con sede en el pueblo de Tarapacá es consignada como "inteligente en el idioma castellano" y, seguramente, bilingüe (AN, AJI, Legajo 162, Pieza 6, 1862). En cambio, años antes, también en un juicio, ahora una causa criminal por abuso de autoridad ante el juez de Primera Instancia de Tarapacá, respecto de uno de los testigos llamado Mariano Ticuna, "indígena de la comunidad de Cariquima" (en el altiplano), para quien el juez dispuso que "No entendiendo el idioma español Mariano Ticuna, testigo... se nombra intérprete ad hoc [a] Mariano Alcón" (AN, AJI, Legajo 1557, pieza 3, 1849). 
de estos territorios a Chile. Se menciona las de Putre, Socoroma, Codpa y Livilcar en el sector andino (Palacios, 1974: 78). También familias y localidades que contrataban maestros de primeras letras por propia iniciativa. Sin embargo, la resistencia activa de los residentes peruanos para la incorporación a Chile en su doble versión, la de Tarapacá (negativa a adoptar la ciudadanía chilena) y, en especial, la de Arica y Tacna (conflicto de nacionalidades asociado a una definición plebiscitaria siempre aplazada y en definitiva nunca realizada), también se materializó en el campo de la educación, incluyendo zonas andinas y numerosos alumnos aymaras. Escuelas particulares peruanas, a veces escuelas parroquiales con sacerdotes peruanos, y escuelas públicas chilenas compitieron por crear o sostener lealtades patrióticas, especialmente en las primeras décadas del siglo XX (González, S. 2002b; Díaz y Ruz, 2009b) ${ }^{18}$. Unas y otras impartían docencia en castellano. Las tuvieron los principales poblados en la precordillera de Arica: Putre, Socoroma, Belén, Tignamar, Codpa (González, 2002b; Díaz y Ruz, 2009b); y de Tarapacá: pueblo de Tarapacá, Camiña, Mamiña, Pica y Matilla (González, S. 2002b; Castro, 2004) ${ }^{19}$.

En suma, con el auge de la industria del salitre se integró intensamente a la población indígena aymara concentrada en la pre y cordillera andina, en especial la primera, más cerca de los centros mineros, con mayor población relativa y con una agricultura que se orientó a servir la demanda de productos campesinos de la población salitrera. Un fenómeno en algunos aspectos similar se dio en las tierras altas de Tacna y Arica con la arriería y tráfico de carretas a Bolivia hasta la primera década del siglo XIX, luego con la construcción y funcionamiento del ferrocarril Arica - La Paz y con la minería de altura. Lo anterior se complementó con la administración del territorio por agentes públicos peruanos y más tarde chilenos, la acción policial en las áreas interiores y de frontera, la conscripción militar y la acción escolar en los principales pueblos andinos. La permanencia de un gran contingente de personas con un fuerte sentido de pertenencia peruana,

\footnotetext{
${ }^{18}$ Un testimonio, entre otros. En carta enviada al intendente de la Provincia de Iquique en 1912, s/f, por Vicente López, profesor de la Escuela Elemental de Hombres No 47 de Pica y firmada, además, por otras dos personas a cargo o en relación con las escuelas No 23 y No 31 , se denuncia: "que estando funcionando en esta aldea escuelas peruanas, y siendo la mayoría ó mejor dicho la totalidad de las familias de esa nacionalidad, mandan a sus hijos á esos colegios, lo que trae por consecuencia disminuir increíblemente la matrícula en la escuela Fiscal, por lo cual me permito observar a U.S. se hace necesario poner coto, pues, en dichas escuelas se inculca a los niños ideas en contra de nuestra patria y, además, la persona que atiende una de ellas es bastante descuidado con su conducta y suficientemente propagador del mal ejemplo. [Aparte] Por lo tanto a U.S. ruego se sirva ordenar la inmediata clausura de las escuelas que hago referencia, a fin de dar el impulso que le corresponde a la Fiscal que está bajo sus órdenes (...) [Firma] V. López V.” AIT, Varios 28, 1912.

${ }^{19}$ Cabe mencionar también la conscripción militar obligatoria, cuya implementación en la zona andina está documentada ya para la primera década del siglo XX (Díaz, 2006 y 2009). La instrucción militar se acompañaba de instrucción escolar primaria destinada a alfabetizar al contingente militar, mayoritariamente de proveniencia rural. El analfabetismo caracterizaba en un alto porcentaje a los varones andinos de la región. La lengua de la conscripción y la alfabetización asociada fue el castellano.
} 
incluidos todos o la gran mayoría de los habitantes de la zona andina -indígenas o con ascendientes indígenas- y no indígenas, y la indefinición acerca de la definitiva soberanía de Tacna y Arica, se expresó en resistencia, pasiva y activa, a la ocupación, la anexión y los esfuerzos de asimilación chilenos. Con variantes según se considere Tarapacá o Tacna y Arica (Castro, 2004), en ambos casos la dinámica de asimilación - resistencia se expresó en integración a la región ${ }^{20}$.

\section{LENGUA MINORITARIA, MINORIZACIÓN Y DESPLAZAMIENTO LINGÜÍSTICO DURANTE EL SIGLO XX}

\section{a) Bilingüismo sustractivo, monolingüismo castellano, fronteras sociales y lin- güísticas internas}

El espacio andino se torna progresivamente bilingüe. Este bilingüismo no es socialmente equilibrado en el sentido de que enriquezca el repertorio lingüístico indígena con la lengua nacional y oficial y, en relación con ello, vayan diferenciándose funciones de comunicación hacia fuera (con el castellano) y hacia adentro (con la lengua originaria). Tampoco lo es en el sentido de que esa diferenciación de funciones se estabilice y permanezca en el tiempo. Antes al contrario, progresivamente los usos y ámbitos sociales internos van siendo invadidos por la lengua nacional y, visto en el largo plazo, el bilingüismo no se estabiliza y la lengua indígena retrocede. Esto es lo que lentamente fue produciéndose con el aymara en la segunda mitad del siglo XIX y las primeras tres décadas del siglo XX. El grado en que ello había avanzado entonces fue bien percibido por Luis Barceló, agregado político chileno en Tacna, quien en 1924 realiza una descripción socio-étnica y lingüística de Arica y Tacna en un apéndice a la contrarrespuesta de Chile al árbitro norteamericano en el diferendo sobre Tacna y Arica:

La población de la Provincia de Tacna (departamentos de Tacna y Arica)
tiene una composición étnica que difiere de la del resto de la República (...) De raza indígena americana, o mestiza, son la mayoría de los 15.000 bolivianos y 12.000 peruanos que habitan el país. Los extranjeros provenientes de otros países americanos o de Europa son de raza blanca. En la provincia de Tacna la situación es muy diversa, pudiendo distinguirse claramente en su población cuatro razas diversas, a saber: a) raza blanca; b) raza indígena; c) raza negra, y d) raza mestiza. (...) b). Los indígenas forman casi la totalidad de la población en las regiones del interior de la provincia. Estos

${ }^{20}$ Respecto de las vicisitudes de los funcionarios y agentes públicos chilenos asignados a la región andina de Tarapacá durante las décadas posteriores a la anexión, véase: Castro (2008: 219-233). 
indigenas pertenecen a la raza aymará, que, junto con los "atacamas" y los "quechuas", forman la rama de los "peruvianos" de la familia indigena llamada "andina" (...). Forman parte, en consecuencia, de esa raza, los indigenas de la provincia de Tacna, y los que se encuentran en el interior de la provincia de Tarapacá. La inmensa mayoría, de la casi totalidad de la población de las subdelegaciones de Tarata y Palca, del departamento de Tacna, y de las de General Lagos, Putre, Belén y Codpa, del Departamento de Arica, está constituida por estos indios de raza aymará. Todos esos indígenas hablan el idioma aymará. Los que habitan la parte más oriental de la provincia, es decir, el distrito de Mauri, la subdelegación de General Lagos $y$ las regiones del Departamento de Arica que limitan con Bolivia, hablan exclusivamente esa lengua, sin que se haya difundido entre ellos el idioma español. Esto se debe al hecho de que alli no hay centros de población, sino que los indios viven aislados, a grandes distancias unos de otros, dedicados al pastoreo de sus llamas y alpacas. Los indigenas de las regiones de las quebradas que se extienden al poniente de la altiplanicie, es decir, los habitantes de las subdelegaciones de Tarata (menos el distrito de Mauri), y de Palca, del Departamento de Tacna, y de la parte occidental de las subdelegaciones de Putre, Belén y Codpa, del Departamento de Arica, que viven agrupados en aldeas y caserios, y que tienen contacto constante con los habitantes de las ciudades de Tacna y Arica, hablan el idioma castellano; pero todos ellos practican también su idioma indigena, y se encuentran numerosos individuos, sobre todo entre las mujeres, que no conocen otra lengua que ésta (Barceló, 1924: 777-782)21.

La distribución del bilingüismo queda así bien descrita: Éste se presenta en las zonas agrícolas de la precordillera andina, mientras que el altiplano permanece monolingüe del jaqi aru. Sugiere, asimismo, que las mujeres tienden a ser lingüísticamente más conservadoras. El bilingüismo en Tarapacá probablemente estaba más avanzado que en la precordillera de Arica, a juzgar por la más activa relación con importantes núcleos de población trabajadora no aymara a relativamente corta distancia y por la residencia en cada valle de grupos de familias monolingües del castellano.

La configuración social y lingüística descrita merece ser mejor explicada. La sociedad andina regional intensificó a partir de la segunda mitad del siglo XIX un proceso de diferenciación social que combinó estratificación con una nítida impronta espacial de la misma. Emerge un estrato de campesinos pudientes y pequeños empresarios que expanden sus bienes y operaciones en la arriería, el comercio con las zonas interiores y los productos agrarios para el mercado. Las

${ }^{21}$ Consúltese también, Díaz y Ruz (2009a). 
diferencias económicas y de poder que concentran se originaron de su relación con las economías empresariales mineras y con su participación en el circuito mercantil con base en Arica y Tacna. Este grupo radicó preferentemente en algunos centros aldeanos precordilleranos como Pica, Tarapacá, Camiña, Codpa, Belén y Putre, en tanto que los pequeños campesinos lo hacían en esos mismos valles y en las tierras altas (altiplano). Cabe destacar que la diferenciación comentada es económica y también política a través del control de la administración local por parte del grupo influyente, de su influencia en el nivel provincial del Estado, de las relaciones con casas comerciales y con empresas. Y también sociocultural, en el sentido que ese estrato se componía de familias "blancas" o mestizas, locales o forasteras, y también de otras con indudables ancestros indígenas, pero segregadas de los "indios" que, mayoritariamente, integraban el grupo subalterno. Sin embargo, ya no definible como un estamento social sino, propiamente, como un estrato en un sistema de clases regional. Este último mantenía la lengua indígena y reproducía otros signos de diferencia como la vestimenta. Sus miembros trabajaban y vivían como "indios": en situación de pobreza, analfabetos, "atrasados", con costumbres no "civilizadas". Ellos eran los campesinos pobres, los trabajadores rurales, los criadores de ganado de la alta cordillera. Se configuran así centros locales que concentran posiciones y oportunidades, respecto de la periferia andina donde tales oportunidades son inexistentes o menos expectantes.

Los nexos de los agricultores pobres o de valles más aislados y pastores de las comunidades altoandinas con las tierras bajas, los valles, la minería del desierto y la costa fueron mediados por los agricultores, arrieros, comerciantes, pequeños funcionarios y autoridades de o asentados en los valles y precordillera andina que integraban el grupo dominante. Las relaciones de que se nutrió esta mediación (intercambios asimétricos, peonaje, diferencias de prestigio y autoridad) dieron origen a la estratificación indicada y, si acogemos los códigos sociales que consideró, a una forma de dominación estamentaria no institucionalizada. Constituyeron un modo de contención social y cultural de unos (que contribuye a su conservadurismo cultural y lingüístico), a la vez que un medio para la proyección hacia afuera de los otros (hacia los centros económicos y de poder en la minería del desierto y de la costa) (Gundermann, 2001: 273-338). Por lo tanto, ese relativamente mayor conservadurismo no es una cuestión de proximidad geográfica o de accesibilidad de un grupo respecto de otros, sino que de relaciones económicas, sociales y políticas, de las que cercanía y acceso es sólo un parámetro entre otros.

A medida que una parte de la población andina se castellaniza, alfabetiza y, eventualmente, se diferencia socialmente de sus congéneres a través de la acumulación de tierras, bienes y capital de trabajo, deja de calificárseles de "indios". Ello puede entenderse mejor por el carácter relativo (a la posición económica, el estatus social y el capital cultural) y situacional (quiénes y bajo qué circunstancias interactúan) de la condición de "indio", luego que desde mediados del siglo XIX fueran 
abatiéndose las instituciones neocoloniales ("contribución indigenal", tierras de reparto, alcaldes de indios) que todavía los posicionaba como un estamento social (Gundermann, 2001; para el caso andino chileno). En esta área meridional como en toda la sierra peruana, ya avanzando el siglo la de "indio" fue adquiriendo la forma de una categoría social de límites difusos, derivado de la posición relativa de quienes así son tipificados o excluidos. De esta manera es posible entender la existencia de fronteras sociales cambiantes entre "indios" y no indios al interior de lo que todavía en la primera mitad del siglo XIX era considerado un espacio andino (en el sentido de poblado por indígenas). El desplazamiento de esas fronteras sociales se dirigió hacia la altura, desde los valles más ricos y dinámicos a los sectores agrícolas marginales y en dirección de las comunidades altoandinas, a medida que en los primeros se ampliaba el contingente de aquellos que experimentaban procesos de movilidad social y cultural y se confirmaban las posiciones sociales expectantes de quienes ya las poseían.

El establecimiento de fronteras sociales y su configuración espacial tiene correlatos lingüísticos y relaciones recursivas entre una y otra dimensión. Si la condición subalterna participa de la continuidad lingüística, al mismo tiempo el monolingüismo aymara o el bilingüismo deja en la condición de "indio" a quienes poseen ese capital lingüístico. Y, a la vez, en determinadas situaciones de interacción social, dejan fuera de lo indígena a aquellos andinos monolingües del español. En la moderna historia andina regional la lengua indígena es así un importante marcador de diferencias de tipo sociocultural. Y ellas tienen una expresión espacial: el espacio del "indio" aymarófono tiende a desplazarse hacia la altura. Ese desplazamiento se mantuvo por relativamente largo tiempo, aproximadamente hasta principios la década de 1970, cuando se intensifican las emigraciones desde las tierras altas a los valles y los centros urbanos del desierto y la costa. Las razones de la estabilización de esos límites sociales y lingüísticos deben ser precisadas. Lo hacemos a través de una doble hipótesis: la de la contención social al interior del espacio andino, ya presentada, y la del desinterés relativo del Estado para expandir la escuela a toda la región andina. Esto último lo abordaremos en el apartado siguiente.

\section{b) Escuelas, conscripción militar y policía: alfabetización, "civilización” y ciuda- danía en el siglo XX andino regional}

La expansión de la escuela pública en la zona andina de valles se llevó a efecto a partir de la década de 1930. En parte como resultado de la excedencia de escuelas en las oficinas salitreras y pueblos del desierto cerradas por la $\mathrm{crisis}^{22} \mathrm{y}$, en parte, por la propia demanda de las comunidades. Con esto se logra densificar la

${ }^{22}$ Esto está bien documentado para Tarapacá por González, S. (2002b: 63-75). 
red escolar en la zona andina de Tarapacá para llegar, en las décadas siguiente y subsiguiente, a cubrir la totalidad del espacio precordillerano, aun las localidades más alejadas. Obtuvieron escuelas: Huatacondo, Matilla, Parca, Sibaya, Coscaya, Huaviña, Chusmiza, Pachica, Macaya, Mocha, Poroma, Chiapa, Jaiña y poblados de la quebrada de Camiña como Moquella, Francia y Chapiquilta, además de Miñemiñe, que se suman a las existentes en el periodo previo ${ }^{23}$.

En el caso de Arica, la creación de escuelas en la precordillera andina en sitios como Socoroma, Putre, Belén y Codpa es anterior en algunas décadas a Tarapacá. Ello se explica por la disputa entre Chile y Perú por esta ciudad y la de Tacna, cuya resolución se alcanza en 1929, quedando Arica y su zona interior para Chile. Desde la década de 1930 hasta mediados de siglo se densifica la red escolar y se inicia su llegada a la alta cordillera. Se crean las escuelas de Chapiquiña, Tignamar y Puquios, junto a las de Alcérreca y Villa Industrial ${ }^{24}$. Las últimas dos escuelas, sintomáticamente, se ubicaban junto a la línea del ferrocarril y ninguna de ellas atendía exclusivamente población andina ${ }^{25}$.

El altiplano de Arica e Iquique permaneció todavía sin escuelas públicas, aunque en la década de 1940 se advertía la necesidad de su creación y se constataba una buena receptividad local para ello. Como señala Héctor Pumarino Soto, secretario de la Gobernación Departamental de Pisagua en mayo de 1945, luego de una visita a la zona interior de la provincia:

\begin{abstract}
Sería (...) de mucha conveniencia para la región la instalación de una escuela en el pueblo de Pisiga o Isluga, ya que hay gran cantidad de niños en estado de ir a la escuela en los pueblos de los alrededores y se nota que hay gran interés de parte de los padres para que aprendan algo (AIT, Gobernaciones, vol. 4, 1944-1945).
\end{abstract}

A su vez, la participación andina en la conscripción militar obligatoria fue bastante activa. Ésta se organizaba a través de oficinas de reclutamiento en las capitales departamentales, con el concurso de los oficiales del Registro Civil y el apoyo de autoridades locales (subdelegados, inspectores de Distrito). La zona interior solía ser visitada por comisiones especiales. Carabineros también ayudó a los empadronamientos, información de llamados y búsqueda de remisos. Ya en la década de 1920 y 1930 el reclutamiento estaba debidamente organizado, alcanzando todas las zonas andinas. Sin embargo, no todos los pobladores de la zona

${ }^{23}$ Un detalle de las escuelas rurales y su localización en un mapa se encuentra en: AIT, Establecimientos Educacionales, vol. 4, 1953/1954.

${ }^{24}$ Dos poblados, uno de trabajadores del ferrocarril de Arica y La Paz, el otro centro de elaboración de azufre proveniente del volcán Tacora, además de pastores, ya en la alta cordillera andina.

${ }^{25}$ AIT, Establecimientos Educacionales, vol. 4, 1953/1954. Véase también Díaz y Ruz (2009b: 375-378). 
hicieron el Servicio Militar por haber excedente de reclutas, por razones de salud o dificultad para ubicarlos. Asimismo, familias con un fuerte sentido de pertenencia peruana enviaron sus hijos como reclutas a Perú, los derivaron fuera de esas provincias o se les ocultó ${ }^{26}$.

El Servicio Militar fue apreciado por los varones andinos como un medio de obtener adiestramiento militar, pero también como una manera de ganar en conocimientos (alfabetización, competencia en castellano o, si lo anterior ya había sido conseguido en la familia y mediante la escolarización previa, al menos "experiencia", algo de "mundo"), o si se quiere, la adquisición de lo que pudiéramos llamar como "artes de la civilización". Y, con todo ello, hombría o construcción de masculinidad en que los varones pasan a la condición de "hombres" ${ }^{27}$. El Servicio Militar sirvió y sirve de bisagra entre la adolescencia y la condición de hombre cabal (capaz de adquirir responsabilidades, fundar un hogar). Un aspecto que suele no advertirse es que la inculcación de que se es objeto en el servicio militar incluye preceptos muy diversos. Además de los nacionalistas de rigor, otros enfatizan la precariedad o rusticidad de la vida rural, su marginalidad, atraso y carencia de desarrollo relativo. Por tanto, si el adoctrinamiento tenía éxito, los jóvenes andinos salían del servicio militar con adiestramiento militar básico, portando identificaciones nacionales chilenas, hecho el tránsito hacia la condición de "hombre", de alguien con mejores conocimientos (más diversos y amplios) y educación (alfabetizado, hablando un castellano fluente si no lo tenía) y, además, con una visión crítica acerca de la vida local de origen ${ }^{28}$. En el presente la participación aymara en la conscripción militar se mantiene fuerte, pero desde algunas décadas a esta parte no tiene lugar la castellanización y alfabetización que fue más común hasta la década de 1960. Una y otra están siendo realizadas por el hogar, la red social inmediata y la escuela ${ }^{29}$. No obstante, lo más probable es que el paso por la conscripción militar siga ejerciendo influencia en la definición de orientaciones de vida modernizantes en los jóvenes andinos.

Justificando por qué alguien tan joven, con 25 años, hacia 1947 asumió como inspector de Distrito (delegado local del gobierno provincial con sede en Pisagua), un hombre nacido en Isluga precisa que los demás miembros de su comunidad: 137).

${ }^{26}$ Mayores detalles en Díaz (2009.) Para el caso mapuche, consúltese González, Y. (2007: 111-

${ }^{27}$ Así nos lo manifestaron en 1986 numerosos varones adultos y adultos mayores de General Lagos y la precordillera de la comuna de Putre con ocasión de entrevistas referidas a cultura, educación y lengua (Gundermann, 1987). La visión que sobre esa experiencia mantenían ya mayores era, por lo general, positiva.

${ }^{28}$ Lo que no debe confundirse con una percepción como soldados, mayormente favorable, en cuanto se les reconoce su tenacidad, resistencia física a la altura, conocimiento del medio andino y sensibilidad musical.

${ }^{29}$ De hecho, los niños aprenden el castellano como primera lengua desde hace ya tiempo y, como algo cada vez más raro, el jaqi aru y el castellano al mismo tiempo. 
no sabian qué es lo que era el cargo, no sabian leer, no tenian nada de educación. Yo, como habia estado en el Servicio [Militar], llegué de la escuela militar, tenía una palabra un poquito más limpia que ellos [con el castellano] y hacia las letras un poquito mejores (...) Y por ahi me eligieron a mi (...) Habia muchos que ni sabian hablar castellano, no comprendian castellano, no sabian. Cerrados no más, si tu les hablabas [en castellano] te quedaban mirando [sin entender, y azorados] enseguida se van no más. (EG).

La labor de la policía de carabineros en la zona no tuvo consecuencias educacionales y lingüísticas comparables a las que se acaban de destacar para la escuela particular o fiscal andina y el Servicio Militar. Quizá pueda destacarse el efecto de desprestigio que sus juicios, a veces abiertamente expresados, acarrearon acerca de lengua y cultura. Pero, aunque real, su influencia en estas materias debe considerarse limitada por la relación esporádica que los pobladores tenían con ellos en las zonas donde no habían dotaciones estables y la distancia social que por lo regular mantenían allí donde hubiera destacamentos permanentes (en las principales aldeas de valles o en áreas de frontera). Por lo demás, con el paso de las décadas los retenes de policía aumentaron y en algunos sitios también sus dotaciones. Testimonios registrados para Socoroma y Caquena indican con claridad que, con más frecuencia de la deseable, la policía chilena asoció lengua aymara con extranjeridad (boliviana o peruana), posesión de la lengua con barrera para la castellanización y alfabetización, conocimiento del aymara con atraso social, o uso de la lengua como medio para la burla y el agravio a sus personas, lo que concito actos de rechazo hacia los hablantes y de presión para su abandono $0^{30}$. Tenemos la impresión que en los últimos años estas ideas están empezando a cambiar.

A partir de la mitad de siglo la red escolar rural en el extremo norte del país se amplía considerando la alta cordillera andina, se densifica algo más en la precordillera andina para incorporar algunos poblados rezagados y se mejora notoriamente la infraestructura educacional con el objeto de disminuir la frecuencia de "ranchos cedidos" (pequeños recintos de adobe y paja facilitados por las comunidades donde se impartía docencia). De esta manera, irrumpen las escuelas en el espacio altoandino limítrofe con Bolivia, el último reducto de un monolingüismo aymara persistente, cuyos antecedentes históricos presentáramos más arriba. Por ejemplo, en la actual comuna de Colchane, en 1953 ya estaban en funcionamiento las escuelas fiscales de Isluga (la $\mathrm{N}^{\circ} 10$ de Pisagua, trasladada al altiplano), la $\mathrm{N}^{\circ} 11 \mathrm{de}$ Enquelga y la de Cariquima. El momento era propicio, pues el segundo gobierno de Ibáñez, quien asume la presidencia en 1952, tuvo la educación como una de sus prioridades (González, S. 2002b:78).

${ }^{30}$ Consúltese: Mamani, M. (1985: 170-173). 
Lo recién descrito parecería indicar que se lleva adelante una arremetida estatal tendiente a completar la cobertura de servicios públicos en la geografía andina nortina y con ello a profundizar la integración al país de los habitantes indígenas de una zona aislada y distante de los centro neurálgicos regionales. Estos cursos de acción estatal, aun para momentos bastante ulteriores a la resolución de problemas de definición de soberanía sobre territorios (Tacna y Arica) y ya bastante apaciguada cualquier animosidad de los pobladores precordilleranos de Tarapacá que se sentían ciudadanos peruanos, suele en la historia regional etiquetarse como "chilenización" (Kessel, 1980, González, 2002a y b; Mamani, J.C., 2005). Esta cara del asunto también suele ser así etiquetada por las autoridades de la época. Por ejemplo, alguna alarma les causa el hecho que niños de Isluga estén en 1944 asistiendo a escuelas bolivianas cercanas. El gobernador de Pisagua, de visita por el sector en noviembre de 1944, señala con preocupación que:

El problema principal de esta región es el analfabetismo. Hay unos DOSCIENTOS NIÑOS entre ambos sexos en edad escolar. Se impone la necesidad de crear una Escuela en Isluga o en Pisiga, que son los dos puntos principales del distrito. Se da el caso de niños que se educan en Bolivia, en Escuelas ubicadas próximas a la frontera, bajo profesores bolivianos pagados por el Fisco de esa nación; sobre lo que han dado antecedentes los vecinos de este sector, dando el nombre del profesor de la Escuela ubicada en el pueblito boliviano de Molla, don Manuel Guayani (así en el original) (AIT, Gobernaciones, vol. 4, 1944-1945).

Lo anterior queda suficientemente encuadrado en las siguientes consideraciones, de cargo del gobernador subrogante de Pisagua al intendente Regional el 28 de febrero de 1946, en materia de necesidades educacionales para la zona interior de la provincia:

En estos sectores, ya no se trata sólo de un simple problema de educación, sino que, al mismo tiempo, de chilenización, por ser sectores de raigambre extranjera por haber sido territorios peruanos o bolivianos y por su vinculación mantenida hasta la fecha a esas naciones. Como un ejemplo, puede apreciarse el que los niños chilenos de Isluga, por ejemplo, concurran a una Escuela ubicada en territorio boliviano, en donde, lógicamente, no habrá conceptos educacionales que honren a nuestra Patria (AIT, Gobernaciones, vol. 1, 1946-1948).

Bien, pero no se repara suficientemente que ya varios años antes, tanto como decir mediados de la década de 1940, esas comunidades aisladas, monolingües y tradicionales venían implementando medidas propias tendientes a la adquisición 
del castellano y a la alfabetización: contratando profesores bolivianos o chilenos no profesionales, a veces alguno normalista y solicitando escuelas y designación de profesores:

Actualmente en la localidad de Mauque hay un profesor que ha sido contratado por los habitantes del pueblo (...) y a cuya escuela van niños desde grandes distancias, pero es el caso que esta persona es solo un aficionado de buena voluntad, pero que carece de los conocimientos necesarios y desconoce en absoluto la pedagogía. El profesor en referencia se llama Faustino Ayaviri y es natural del pueblo de Chizmiza [Chusmiza] ${ }^{31}$ (Héctor Pumarino Soto, secretario de la Gobernación Departamental de Pisagua en informe de visita de mayo de 1945, AIT, Gobernaciones, vol. 4, 1944-1945)32.

Pero no sólo eso, sino que, además, ellos mismos vinculan educación con adhesión a una pertenencia chilena:

DENUNCIA DE LOS VECINOS DE ISLUGA: En el mes de septiembre de 1953, se recibió en esta oficina una enérgica protesta de los padres y vecinos de Isluga, por la ausencia del Director [Don Sergio Cárdenas M.] que les impedía celebrar el Aniversario Patrio, como sentida necesidad patriótica $y$ de verdadera chilenidad (AIT, Establecimientos Educacionales, vol. 4, 1953-1954) $)^{33}$.

¿Simple apelación a una condición de activos chilenos en la frontera con la finalidad de motivar a las autoridades para preocuparse más del funcionamiento de los establecimientos escolares fiscales? Seguramente está presente tal recurso, pero no es un asunto puramente instrumental.

La demanda interna antecede, entonces, a la oferta o imposición externa de servicios escolares. Podría, de esta manera, hablarse de una convergencia de motivaciones e iniciativas para la obtención de servicios estatales, los educacionales entre los principales, pero no los únicos (también policía, órganos de justicia, funcionarios de gobierno interior). Esa convergencia radica en algunos supuestos o premisas acerca del valor de la castellanización y alfabetización para grupos so-

${ }^{31}$ Mauque es una comunidad sucesorial de la zona de Isluga. Chusmiza es un poblado de la precordillera de la quebrada de Tarapacá.

${ }^{32}$ También la solicitud de la comunidad de Cariquima en junio de 1955, canalizada a través del inspector del 4to. Distrito de Cariquima, para que la Dirección Provincial de Educación Primaria les entregara subvenciones, material escolar y mobiliario a la escuela particular que por ese entonces estaban haciendo funcionar. Archivo de la Intendencia de Tarapacá (AIT), Establecimientos Escolares, s/v, 1945.

${ }^{33}$ Un caso análogo es el de la comunidad altoandina de Cancosa. Al respecto: González, S. (2002b: 82-84). 
ciales marginales como las comunidades campesinas de la cordillera andina. Para unos, autoridades y agentes públicos, se trata de la integración o incorporación a la región de zonas fronterizas aisladas donde la presencia del Estado es débil, la soberanía nacional no está cabalmente resuelta, las identificaciones nacionales son incipientes o no existen, la participación ciudadana de sus pobladores es insuficiente, etc. Para los otros, comunidades aymaras actuando desde sus circunstancias locales, se trata de obtener servicios valorados de algunas agencias públicas (educación, justicia, gobierno), mejorar la infraestructura de comunicaciones y transporte y adquirir herramientas culturales consideradas indispensables para el futuro (alfabetización, lengua castellana). Esos propósitos se elaboraron internamente, aunque en ello seguramente jugó un papel importante su relación con la precordillera andina (por ese entonces bilingüe o monolingüe del castellano en algunos sitios y notoriamente más integrada que el altiplano) y con poblados bolivianos cercanos (como el de Llica, desde donde provienen los docentes de las primeras escuelas espontáneas en el altiplano sur).

Vistos así, estos cursos de acción convergentes e, incluso, una iniciativa aymara anticipada en demanda de escuela y aprendizaje del castellano difícilmente podría llamársele de "chilenización". Y ello porque no está presente una dimensión crítica: la de una inscripción de sujeto colectivo nacional antagónico, ni tampoco algún tipo de resistencia a la acción estatal. Por el contrario, ésta más bien sale al paso, busca ponerse en línea con la demanda y la acción de las comunidades andinas.

c) Modernización, regionalización de la sociedad aymara y la dinámica de la lengua

Con posterioridad a la llegada de la escuela fiscal al altiplano se producen cambios dignos de notar a los fines de caracterizar la dinámica del bilingüismo. Primero, se amplía y densifica la red escolar en toda el área andina. Se crean numerosas escuelas públicas entre 1960 y 1990 en sitios como Colchane, altos de Pica, Camiña, la quebrada de Camarones, los altos de Putre y, sobre todo, General Lagos. Toda localidad con niños aymaras queda en la práctica cubierta por servicios escolares. Se suman a las ya enumeradas: Cancosa en la actual comuna de Pica; Villablanca, Chijo, Ancuaque, Quebe, Mauque, Escapiña y Pisiga Choque en Colchane (ya en la década de 1990 una escuela en Panzuta, sector de Parajalla); Yala-Yala, Apamilca y Nama en Camiña; Guallatire, Parinacota y Caquena en los altos de Putre; Murmuntani en la precordillera de esta misma comuna; Esquiña, Cobija, Guañacagua, Chitita, Illapata y, más recientemente, Parcoaylla (una lejana estancia de pastores en la precordillera alta) en la comuna de Camarones; Visviri, Ancolacane, Cosapilla, Chujlluta, Chislluma, Guacoyo, Humapalca y Colpitas en General Lagos. Además, iniciándose la década de 1980 se crean escuelas de 
concentración fronteriza en la precordillera andina (Putre, Ticanamar) y altiplano (Visviri, Colchane, Cariquima) de mayor tamaño que cualquier establecimiento escolar previo y con un régimen de internado. De esa manera, la cobertura escolar rural regional se completa y la alfabetización en castellano también.

La ampliación de la red escolar se realiza en complemento con una progresiva mayor presencia de servicios públicos y su personal. Registro Civil, retenes de Carabineros de Chile en la frontera y en todas las aldeas de cierto tamaño, contingentes militares estables (como en Putre), rondas médicas, estaciones médico-rurales, más recientemente médicos estables, servicios del agro, servicios de vivienda rural, instituciones y programas de la política indígena, etc., forman parte del paisaje institucional y social andino de los últimos tiempos. Con la creación en 1980 y ulterior puesta en funciones de municipios exclusiva o mayoritariamente indígenas (Huara, Camiña, Colchane, Camarones, Putre y General Lagos), se constituyen gobiernos locales que prestan importantes funciones y coordinan la acción local de muchos servicios públicos.

Asimismo, las posibilidades de desplazamiento y de comunicación por la zona cambian considerablemente con el paso de los años. Durante el último medio siglo, el interés de llevar a efecto una más activa integración de esas zonas interiores y sus pobladores, unido a una sostenida demanda de las comunidades por caminos de acceso (y servicios públicos: escuelas, registro civil, policía, vialidad) llevó a un cambio radical de situación en esta materia. Una profusa red de caminos terrestres va desarrollándose y uniendo las capitales regionales (Iquique y Arica) con las zonas interiores y cada comunidad andina. La movilidad de las personas andinas se acrecienta considerablemente, así como las relaciones con personas no indígenas ${ }^{34}$. La radio comunicación y, más recientemente, la telefonía digital e internet son recursos de comunicación también presentes en la vida rural andina.

Sin embargo, no se trata sólo de que el acceso al espacio andino haya mejorado considerablemente ${ }^{35}$, o que las agencias públicas y los gobiernos locales tengan una presencia continua y significativa para los pobladores. Estos mismos han experimentado una extensiva redistribución de su población, emigrando masivamente a los centros urbanos regionales y a áreas con mejores posibilidades de desarrollar

${ }^{34} \mathrm{Si}$ a mediados de siglo llegar a Isluga o Cariquima demandaba un par de días en mula desde el sitio de la precordillera más cercano hasta donde pudiera acercarse un vehículo motorizado, desde la década de 1980 sólo unas pocas horas separan Iquique de las comunidades altoandinas junto a la frontera. En el presente, la carretera de Iquique a Oruro disminuye aún más ese tiempo. Algo similar se presenta con la carretera que une Arica y La Paz, que sirve a una profusa red de caminos secundarios en las comunas de Putre y General Lagos. Las posibilidades de transporte y circulación también se extienden hacia Bolivia, pero son poco usadas. Más bien ocurre en contrario: personas aymaras que ven en el norte de Chile un lugar atractivo para instalarse o desarrollar actividades comerciales.

${ }^{35}$ De lo cual habla un flujo turístico en aumento por la zona para admirar los notables paisajes y fauna de la cordillera con sus volcanes, cerros nevados, salares, parques nacionales, lagunas, camélidos silvestres, etc. 
agricultura para el mercado. Las emigraciones andinas son antiguas, tanto como decir finales del siglo XIX e inicios del XX, con la salida de numerosos ciudadanos peruanos de los valles de Tarapacá y Arica. El espacio agrario dejado por ellos fue llenado por campesinos andinos de quebradas y valles menores de la misma precordillera, junto con emigrados desde el altiplano o Bolivia. La crisis salitrera que se abre a partir de 1929 acarrea luego una crisis análoga en la economía campesina de los valles de Tarapacá, dependiente de la demanda de fuerza de trabajo y productos agrícolas que se origina en los campamentos y pueblos mineros. Esa crisis derivó en emigraciones a los centros urbanos regionales Arica e Iquique en las décadas de 1950 y 1960. En Arica, el declive del arrieraje luego de la puesta en funciones del ferrocarril de Arica a La Paz, y de las faenas mineras en la cordillera, unido al atractivo generado por la activación de Arica como Puerto Libre (1952-1961), Polo de Desarrollo Industrial (1962-1974) y expansión de la frontera agrícola en Azapa y Lluta (1975-1995) se expresó también en la salida de numerosas familias de la precordillera. En las dos zonas, el relevo de los que salieron de la precordillera lo hizo un sector de ganaderos de las comunidades altoandinas (Acevedo, Gálvez y Raab, 1970; González, H., 1996a y b, 1997a y b, 2009; Gunderman, 2001: 273-338; 2002). En las décadas de 1980 y 1990 destaca la emigración directa, sin una etapa intermedia en los valles, desde el altiplano hacia los puertos de la región y, secundariamente, la continuidad de la emigración desde la precordillera andina con los mismos destinos.

Tabla I. Año de migración según pisos ecológicos y microrregiones de proveniencia.

\begin{tabular}{|c|c|c|c|c|c|c|c|c|c|c|c|c|}
\hline \multirow[t]{2}{*}{$\begin{array}{l}\text { Año de } \\
\text { emigración }\end{array}$} & \multicolumn{2}{|c|}{$\begin{array}{l}\text { Altiplano } \\
\text { norte }\end{array}$} & \multicolumn{2}{|c|}{ Altiplano sur } & \multicolumn{2}{|c|}{$\begin{array}{l}\text { Subtotal } \\
\text { altiplano }\end{array}$} & \multicolumn{2}{|c|}{ Valles norte } & \multicolumn{2}{|c|}{ Valles sur } & \multicolumn{2}{|c|}{$\begin{array}{l}\text { Subtotal } \\
\text { valles }\end{array}$} \\
\hline & No & $\%$ & No & $\%$ & No & $\%$ & No & $\%$ & No & $\%$ & No & $\%$ \\
\hline 1994-1990 & 16 & $13,3 \%$ & 22 & $26,2 \%$ & 38 & $18,6 \%$ & 10 & $7,1 \%$ & 14 & $7,6 \%$ & 24 & $7,4 \%$ \\
\hline 1989-1985 & 15 & $12,5 \%$ & 18 & $21,4 \%$ & 33 & $16,2 \%$ & 9 & $6,4 \%$ & 23 & $12,5 \%$ & 32 & $9,9 \%$ \\
\hline 1984-1980 & 18 & $15,0 \%$ & 10 & $11,9 \%$ & 28 & $13,7 \%$ & 7 & $5,0 \%$ & 15 & $8,2 \%$ & 22 & $6,8 \%$ \\
\hline $1979-1975$ & 17 & $14,2 \%$ & 18 & $21,4 \%$ & 35 & $17,2 \%$ & 13 & $9,3 \%$ & 16 & $8,7 \%$ & 29 & $9,0 \%$ \\
\hline $1974-1970$ & 16 & $13,3 \%$ & 4 & $4,8 \%$ & 20 & $9,8 \%$ & 16 & $11,4 \%$ & 33 & $17,9 \%$ & 49 & $15,1 \%$ \\
\hline 1969-1965 & 18 & $15,0 \%$ & 7 & $8,3 \%$ & 25 & $12,2 \%$ & 22 & $15,7 \%$ & 20 & $10,9 \%$ & 42 & $13,0 \%$ \\
\hline 1964-1960 & 11 & $9,2 \%$ & 2 & $2,4 \%$ & 13 & $6,4 \%$ & 14 & $10,0 \%$ & 24 & $13,0 \%$ & 38 & $11,7 \%$ \\
\hline $1959-1955$ & 6 & $5,0 \%$ & 3 & $3,6 \%$ & 9 & $4,4 \%$ & 16 & $11,4 \%$ & 13 & $7,1 \%$ & 29 & $9,0 \%$ \\
\hline $1954-1950$ & 2 & $1,7 \%$ & $-\cdots$ & --- & 2 & $1,0 \%$ & 16 & $11,4 \%$ & 10 & $5,4 \%$ & 26 & $8,0 \%$ \\
\hline $1949-1945$ & --- & --- & -- & --- & -- & -- & 7 & $5,0 \%$ & 7 & $3,8 \%$ & 14 & $4,3 \%$ \\
\hline 1944-1940 & -- & -- & $-\cdots$ & -- & $-\cdots$ & $-\cdots$ & 5 & $3,6 \%$ & 3 & $1,6 \%$ & 8 & $2,5 \%$ \\
\hline 1939-1935 & 1 & $0,8 \%$ & -- & -- & 1 & $0,5 \%$ & 3 & $2,1 \%$ & 3 & $1,6 \%$ & 6 & $1,8 \%$ \\
\hline $1934-1930$ & --- & -- & -- & --- & -- & -- & 2 & $1,4 \%$ & 3 & $1,6 \%$ & 5 & $1,5 \%$ \\
\hline Totales & 120 & $100 \%$ & 84 & $100 \%$ & 204 & $100 \%$ & 140 & $100 \%$ & 184 & $100 \%$ & 324 & $100 \%$ \\
\hline
\end{tabular}

Fuente: Tomado de Gundermann (2001), con base en encuesta de González y Gundermann (1995). 
La pauta de integración aymara regional moderna resultante no se expresa en abandono de la agricultura, los pueblos y comunidades de origen, como tampoco en un masivo asalariamiento urbano. Lo notable de la redistribución regional de la población aymara es que se realiza fundamentalmente desde bases agrarias, capacidades y opciones culturales propias, por lo que despliega una profusa actividad en relación con la agricultura, el comercio de productos agropecuarios y el transporte de personas y productos agrícolas. Lo anterior se efectúa con el concurso de activas redes de parientes, comuneros, vecinos y amigos ${ }^{36}$. De esta manera, aun cuando la sociedad aymara ha protagonizado durante el último medio siglo una fundamental redistribución regional de su población, transformándola principalmente en urbana, ello no ha significado siempre y en todos los casos fragmentación y atomización social. Grupos, organizaciones y redes aymaras conectan lo rural y lo urbano, los emigrados y sus familias con las comunidades de origen, las actividades agropecuarias con la residencia urbana para fines de educación de los hijos o trabajo principal, la cultura local con sus cultores urbanos.

La lengua general de esta nueva situación social regionalizada es el castellano, ya que todos los aymaras hablan la lengua nacional y sólo una minoría tiene hoy competencia -por lo demás muy heterogénea- en la lengua vernácula. Como cabe suponer, el jaqi aru también se dispersa por la región: hay más hablantes hoy en la precordillera que ayer y, de todos modos, más que antes en zonas agrícolas bajas y en los puertos, resultando de ello una paradoja: posiblemente haya más personas con conocimientos de la lengua vernácula en los centros urbanos regionales o en valles agrícolas como Azapa y Lluta que en el altiplano. Pero la proporción de aquéllas es menor respecto del grupo de los aymaras del altiplano y todavía mucho menor respecto de los no indígenas con quienes mantienen fluidas relaciones. Asimismo, las condiciones sociales para su empleo, aprendizaje y transmisión, o los dominios de uso, son claramente más restrictivas.

\section{EL DESPLAZAMIENTO LINGÜÍSTICO EN CLAVE MICROSOCIAL (INDIVIDUAL, FAMILIAR, LOCAL)}

¿Cómo se experimenta individual, familiar y comunitariamente la adquisición del castellano en tanto lengua dominante y, en relación con lo anterior, el desplazamiento de la lengua originaria? Debemos acudir a las biografías de personas que vivieron esos momentos. Las primeras etapas en el bilingüismo de dos personas del altiplano pueden ser ilustrativas.

${ }^{36}$ Para el estudio de un caso de grupo local aymara con intensa emigración y la red social construida en esta situación de translocalización, confróntese: Gundermann y González (2008). 
Ernesto G. es originario de Isluga, nacido en la década de 1930 y ya fallecido. Considera los siguientes momentos. Primero, aprende en su hogar el aymara pero, al contrario de lo que era común por ese entonces entre sus coetáneos, adquiere el castellano de niño cuando su padre lo lleva a Antofagasta para dejarlo como "mocito" con una familia andina de la precordillera: "de 6 ó 7 años me llevó mi papá a Antofagasta, de chiquito. De ahi ya sali hablando [castellano]" (EG). Estuvo allí alrededor de 2 años, hasta que su padre fue a buscarlo. Luego, de vuelta a Isluga mantuvo comunicación fluida en castellano con un vecino, oriundo de Sotoca en la precordillera, comerciante e instalado en la frontera. Este mismo arregló enviar a sus hijos pequeños a una escuela en el pueblo boliviano de Llica, pagando un profesor y una pensión en casa particular. Para Ernesto se sumó entonces que: "cuando yo fui niño estuve en la escuela de Llica. Acá no habian profesores. Yo estuve desde el año 41 en la escuela de Llica... Yo estuve casi 2 años allá...". Otros tres niños varones de estancias vecinas también asistieron. Allí se alfabetiza y gana algo más desenvoltura con el castellano. Huérfano de padre, en la adolescencia moviliza mercaderías en llamas cargueras y burros, aprovechando sus vínculos con comerciantes instalados en la frontera. Algunos años más tarde es llamado a la conscripción militar, donde enfrenta nuevamente un ambiente lingüístico completamente castellano y se impregna de ideas de cambio y progreso que buscará inculcar entre su gente.

Eugenio Ch., oriundo de Cariquima, ocupa una posición algo distinta que el caso precedente en el continuo que va entre el monolingüismo aymara y castellano. Si en aquél corresponde a niños que se castellanizan y alfabetizan a través de iniciativas particulares de escolarización, en éste se trata de la primera cohorte de niños monolingües de una comunidad que a través de su incorporación a una escuela se castellanizan y alfabetizan. Eugenio nació en 1941 y tuvo por primera lengua el jaqi aru. Experimentó un contacto continuo con el castellano recién al momento de ingresar a la escuela:
A los seis años me pusieron en la escuela de Cariquima con un profesor particular, pero pagado por el pueblo. Yo en esos tiempos no aprendi nada (...) no sabia hablar castellano. La verdad es que yo a la edad de ocho años empecé a hablar algunas palabras en castellano.

Poco después se funda la escuela fiscal en Cariquima y el carácter enérgico del profesor a cargo, según el relato de su ex alumno, le permitió avanzar en el aprendizaje de la lengua y alfabetizarse: "[después] llegó un profesor que se llamaba Carlos Chivi. De ahi estaría como tres años con ese profesor Carlos Chivi, en Cariquima. Yo ahi aprendi castellano, aprendí a leer y aprendí a escribir, hasta la edad de nueve años" $(\mathrm{ECH})$. Luego su familia se trasladó a la localidad agrícola de Poroma, en la parte alta de la quebrada de Tarapacá y allá también asistió a la escuela, encontrando 
una gran mayoría de alumnos monolingües y un ambiente lingüístico comunitario también castellano. Allí concluyó el aprendizaje formal del español y su etapa escolar a la edad de 12 ó 13 años.

¿Cómo se realiza la comunicación entre el profesor y los alumnos cuando uno es exclusivamente castellano hablante y los otros, todos o la gran mayoría, monolingües del aymara? Esta situación fue frecuente en la década de 1950 y en la siguiente, una vez conformada la red escolar en la alta cordillera:

... las enseñanzas eran todas en castellano. Yo realmente estaba en la luna. O sea que [de] la explicación que el profesor daba en castellano no entendía nada. Yo tenía que aprender castellano más o menos bien para entenderle las explicaciones del profesor. Eso me costó bastante. A medida que iba aprendiendo, conociendo las letras, tratando de escribir, ya iba aprendiendo dos cosas: aprendiendo castellano [y, con ello, aprendiendo a comprender las explicaciones], y aprendiendo las palabras en castellano y lo que decía también en aymara. Es decir, yo era aymarista legitimo. Para saber la palabra al castellano habia que saberse también lo que dice en aymara, para asi poder darse cuenta qué es lo que decía (...) ese es el asunto grave que teníamos. Nos costaba mucho aprender las explicaciones. A nosotros nos pasaban una tarea y habia palabras en castellano y [nos preguntábamos] ¿qué dirá acá y cómo dirá acá? Me reventaba la cabeza (ECH).

En estos casos, los padres también eran por lo general monolingües, las mamás en particular, y poco o nada podían ayudar. Algunos hombres en el Cariquima de ese entonces eran bilingües, pero tenían conocimientos incipientes del castellano, un aprendizaje que nada debía a las familias de nacimiento y tampoco a procesos de escolarización, sino que al contacto con castellano hablantes en las aldeas agrícolas de la precordillera. Este era un castellano muy interferido por el aymara y, como dice la persona que vivió esa experiencia cuando niño: "el papá, bueno, que contestaba a medio hablar castellano, pero ellos hablaban no más, no estudiaban; los que estudiaban éramos nosotros" (ECH); es decir, que aunque supieran algo de español eran completamente analfabetos y lo que sus monolingües hijos enfrentaban era el aprendizaje de la lectoescritura en castellano sin dominar esta lengua.

Luego que hubo cohortes bilingües, la comunicación con los profesores mejoró y, con ello, el propio proceso escolar. El relato del profesor Vicente Malinarich, quien trabajó a partir de 1963 en Pisiga Choque, en la actual comuna de Colchane, es bastante ilustrativo. Recuerda que "los niños que tuvo hablaban castellano y aymara porque "las escuelas (en Pisiga) llevaban ya unos diez años, asi que los niños ya habian entrado al lenguaje castellano" (así en el original) (González, S., 2002b: 125). Se puede advertir de este relato que la expansión del bilingüismo se desarrolla rápido en Pisiga Choque, una comunidad previamente monolingüe. En 
cosa de una década de escuela los nuevos alumnos que recibió el Sr. Malinarich ya dominaban de entrada suficiente castellano como para que la comunicación en el aula no presentara obstáculos insalvables. No se quiere con esto decir que en esa década nada había pasado en materia de bilingüismo si acaso no estuviera la escuela. Mal que mal, en la inmediata Bolivia y en el mismo sector había otras escuelas, la percepción de la necesidad del castellano se había generalizado, la ambición por una más profunda integración regional era notoria, los primeros bilingües con alguna competencia en castellano ya habían hecho su aparición en la comunidad ${ }^{37}$, el contacto con arrieros y comerciantes aumentaba, los viajes a la precordillera eran frecuentes, etc. No obstante, la escuela sí parece multiplicar el impulso castellanizador.

No sin algunos reparos sobre sus efectos colaterales (básicamente, la sustracción de los escolares del cumplimento de roles laborales importantes en el pastoreo) ${ }^{38}$, los padres pensaban que la castellanización y alfabetización eran muy convenientes: "porque nosotros estábamos viviendo en otro mundo y se daban cuenta que la educación que venía era muy importante para ellos, para no quedarse en un mundo muy separado, para no quedarse tan ignorante..." (ECH) ${ }^{39}$. A los profesores se les reconoce como activos impulsores del cambio. Eugenio $\mathrm{CH}$. recuerda que:

en la escuela me decian los profesores que ustedes tienen que educarse y ustedes tienen que salir de las chalas, tienen que salir de las ropas tejidas que usan, tienen que salirse los gorros que usamos, ustedes tiene que cambiar, ustedes no deben ser como fueron sus viejos, tienen que cambiar de lo que son tus viejos, ustedes son gente nueva que tienen que cambiar, irse a la ciu-

\footnotetext{
${ }^{37}$ Principalmente varones jóvenes o adultos, por su más amplia red de relaciones que los exponía y obligaba a un aprendizaje siquiera elemental del castellano.

${ }^{38}$ En estos primeros momentos algunas familias no le otorgaron importancia a la escuela, a la enseñanza del castellano y a la alfabetización. Su introducción fue en parte buscada por un grupo de interesados, en parte impuesta por estos mismos con el apoyo de funcionarios públicos como carabineros, en parte estimulada por el bajo prestigio que se otorgaba al analfabetismo y el monolingüismo generalizado que por ese entonces todavía mantenía una comunidad como la de Isluga, respecto de las comunidades de la precordillera andina con las que se relacionaban activamente con fines de comercio, peonaje e intercambio complementario. Este fenómeno es descrito así: "Les era igual. Si se traía un profesor: jes flojo!, decian. Les está enseñando más a jugar, a pelear [que a trabajar]. Cuando jugaban a la pelota, era como enemigo para la gente... No les gustaba, no estaban acostumbrados con eso. Que los cabros se hacian flojos, que se tronchan los dedos a pata pelada jugando pelota. En esos tiempos no tenian zapatos. $Y$ de ahi papá y mamá decian: mi hijo está estudiando, traen a esa gente para profesor, para echar a perder a mis hijos, no quiere pastear llamos, dicen, no quiere hilar, dicen, no quiere sembrar quinoa; quiere ir para allá no más a flojear. Es lo primero que decían cuando andábamos con Ismael Taucare casa por casa, para que firmaran para hacer número para pedir la escuela la las autoridades educacionales o provinciales]. Se enojaban unos, no quería otros, ¡quéee; decían: está abusando de nosotros" (EG).

${ }^{39}$ Los padres en Cariquima tenían interés de que sus hijos asistieran a la escuela para "que aprendieran a leer (...) para que no se viva encerrado como ganado, quieren que despierten, que conozcan mucho más de lo que existe ahi [en su lugar], como ser: qué es lo que pasa en una ciudad, qué se puede hacer. Para eso sirve mucho" (ECH).
} 
dad, vivir en la ciudad, vivir cómodo. Ese más que nada incentivaban los profesores, los educadores que venian acá siempre con las ideas de la ciudad $(\mathrm{ECH})^{40}$.

Por lo demás, la red de relaciones microrregionales de la que formaban parte con Bolivia y con la precordillera o la zona salitrera los ponía frecuentemente ante un espejo que les devolvía una imagen devaluada: "En otras partes las gentes se admiraban, se fijaban. Siempre decian: ;Isluguita, isluguita!, decian. Discutían, en cualquier discusión le decían: -jIsluga, Isluga, estai muy caído, muy atrasado!, decian" (EG).

Un papel destacado cumplieron dirigentes, autoridades locales y personas influyentes, especialmente jóvenes con algo más de "mundo" y escolarización que los demás, en la llegada de las escuelas, la demanda de profesores, la apertura de caminos, la instalación de servicios (retenes de Carabineros, Registro Civil, además de escuelas). Ellos cumplieron un papel de mediación, pero también de imposición respecto de familias y comunidades con frecuencia con pocos elementos de juicio e indecisas frente a los cambios que se estaban promoviendo. Recuerda un antiguo inspector de Distrito de Isluga que cuando cumplió el cargo allá por el año 19471949, imbuido de propósitos progresistas para su comunidad, propuso e impuso diversos cambios (higiene, vestuario, alimentación, vivienda, escuela, etc.) porque:

...yo quería vivir como persona civilizada, como en la ciudad, y no en esos tipos antiguos de costumbre. E Isluga ly Cariquima en la misma zona altoandina de la actual provincia de Iquique, y los caserios de General Lagos, más al norte] era el único pueblo que tenía de esos mismos costumbres. Yo me fijaba, porque era muy feo... Entonces de esa manera yo traté de cambiarles $(\mathrm{EG})^{41}$.

En la década de 1960 y en la de 1970 el conocimiento del castellano se generaliza en el altiplano, al mismo tiempo que el monolingüismo castellano de la gente oriunda de la precordillera se acentúa. Y su empleo también se desarrolla, en particular por parte de las nuevas generaciones, imbuidas del prestigio de la

${ }^{40}$ A veces, mediante actos de represión lingüística explícita. En Cariquima durante las primeras décadas de escuela "la lengua aymara todavía se hablaba, no se prohibia [pero] un profesor nuevo, Nelson T., yo recuerdo que en una reunión con los apoderados les probibió [que los niños] hablaran en aymara... Les dijo que sus hijos no debian ser ignorantes y ciegos. Que sean con estudios. Con tenerlos hablando aymara, les dijo, están mezclando una lengua que no está reconocida por el Estado (...). Ha habido profesores que han querido discriminar la lengua aymara (...) El pueblo lo aceptó. Decían: jcierto, cierto!" (ECH).

41 "Después cuando vine yo [de vuelta del Servicio militar, algún tiempo después] se trajo un profesor de Llica, de allá, a impartir clases a Cotasaya"; "Traje profesores particulares de Llica, para Cotasaya, se llamaba Guayllane y el otro Julio Apata" (EG). 
lengua oficial e interesadas en dominarla y usarla. El bilingüismo recién creado se diferencia internamente en las competencias y los usos. Pero, el aprendizaje de la lengua vernácula todavía está asegurado porque la primera lengua aprendida fue usualmente el jaqi aru, porque los padres (los que enviaron a sus hijos a las escuelas recién creadas) eran hablantes asiduos y en la red de relaciones inmediatas (vecindad, comunidad, parentesco, amistad) la lengua originaria permanecía vital.

Pero el proceso avanza y la asimilación de la lengua nacional por la mayoría de las personas es un requisito para que con el paso del tiempo ésta penetre en prácticas sociales y dominios de experiencia cada vez más diversos: educación formal y, progresivamente, también hogar, trabajo, parentesco, comunidad, organización comunitaria, mercado. Además de la acción escolar y de las relaciones extracomunitarias, contribuye a lo anterior la presión interna de los progenitores en la familia y la de los agentes de línea progresista de la comunidad, muy activos desde la década de 1950. Tales presiones no sólo impulsan la adquisición y el uso del castellano, sino que también el abandono de la lengua propia. Fueron $y$, en muchos casos, siguen siendo comunes, tanto la ausencia de resistencia al avance del castellano en los ámbitos intraétnicos y privados, como la autorrepresión familiar e individual para el uso de la lengua vernácula. De esta manera, las cohortes de bilingües escolarizados interrumpen en mayor o menor medida la enseñanza de la lengua propia, y el flujo de su transmisión, que no depende sólo de la enseñanza familiar ${ }^{42}$, sufre diversas restricciones. Es posible que en familias residentes en comunidades con padres castellanizados y escolarizados, las condiciones internas del hogar y de la localidad todavía posibiliten que sus hijos aprendan la lengua aymara. Pero esto ya se hace excepcional en la siguiente generación, en la que padres y comunidad suelen emplear el castellano para la comunicación cotidiana. Aunque con antecedentes previos, esto es lo que ocurre y se desarrolla durante la década de 1980, la de 1990 y la de 2000 en todas las comunidades ganaderas de la alta cordillera ${ }^{43}$.

Según lo planteado, en el altiplano tratamos ahora con un bilingüismo fundamentalmente distinto a aquel de los inicios del aprendizaje del castellano y la llegada de la escuela. Décadas atrás, se trataba de alfabetizarse y adquirir el castellano necesario para la comunicación con un mundo que se abría con rapidez. Ahora, asentado el idioma nacional, éste entra rápidamente a competir con el jaqi aru como lengua de uso cotidiano, prevaleciendo como instrumento de comunicación en las interacciones sociales. Con características propias, tiempo antes un proceso análogo se dio en la precordillera andina. La llegada del castellano se realizó desde una posición de alto prestigio, frente a una lengua vernácula minorizada. Lo que

${ }^{42}$ La comunicación cotidiana no dirigida a los niños, la comunicación con vecinos amigos y parientes o en la comunidad.

${ }^{43}$ Altos de la comuna de Pica, la de Colchane, Putre y General Lagos. 
ha venido ocurriendo después no es sino el desarrollo de una dinámica sociolingüística sustentada en esa posición de prestigio y poder. Varias categorías analíticas son aplicables al proceso y a sus resultados, como bilingüismo substractivo (Lambert, 1977), bilingüismo sin diglosia (Fishman, 1988) o bilingüismo superpuesto (Fasold, 1996), inestable en el caso que analizamos, y cuyas tendencias se dirigen a la substitución de la lengua minorizada.

\section{EL PANORAMA LINGÜÍSTICO ACTUAL}

Considerando autodeclaraciones de competencia lingüística obtenidas en un estudio reciente ${ }^{44}$, la mayoría de la población de 18 años y más en el área estudiada (un $64,5 \%)$ declara carecer de competencia lingüística en alguna lengua indígena. Si se considera sólo al grupo que se autodefine como aymara, un $65,7 \%$ señala poseer competencia en grados variables en su lengua. Estos porcentajes experimentan importantes variaciones en relación con los sectores geográficos: mientras en el altiplano la competencia se eleva a un $95,2 \%$, en la precordillera baja a un $61,2 \%$ y en la zona de valles bajos, oasis y pampa alcanza sólo a un 38,6\%. Lo mismo que la autoadscripción étnica, la competencia en lengua aymara desciende en dirección a los sectores más bajos (Tabla II).

${ }^{44}$ Los antecedentes que presentamos fueron obtenidos a través de una investigación llevada a cabo entre los años 2002 y 2003 para el Programa de Educación Intercultural Bilingüe (PEIB) del Ministerio de Educación, la que incluyó a los pueblos aymara, atacameño y mapuche. Se consideró la población aymara de las comunas de General Lagos y Putre, en la provincia de Parinacota; y de Huara, Camiña, Colchane, Pica y Pozo Almonte, en la de Iquique. Estas comunas y sus comunidades escolares son enteramente rurales, por lo que la muestra es co extensiva con la población comunal. También se incluyeron las localidades de Putre y Pica, consideradas como centros urbanos en la clasificación censal, pero que era necesario incorporar por encontrarse allí una considerable población aymara y establecimientos escolares ejecutando el programa de EIB. Se aplicó una encuesta sociolingüística a una muestra representativa de la población rural existente en las siete comunas mencionadas de acuerdo al Censo del año 2002. La encuesta incluyó la población total, indígena y no indígena de las comunidades escolares estudiadas. Se consideró solamente a los individuos de 18 y más años de edad, por cuanto podían dar mejor cuenta de su acervo sociolingüístico, determinar con mayor precisión su competencia lingüística y entregar, en general, información de mejor calidad. Se trabajó con un margen de error muestral de un 5\%, hipótesis de varianzas del 50\% y un nivel de confianza del 95,5\%. Para la ubicación geográfica de la base muestral y la localización específica de las entidades consideradas en la muestra, se utilizó la información censal y cartográfica del Instituto Nacional de Estadísticas (INE). En la elaboración de la información se privilegió una dimensión geográfica relativa a los pisos ecológicos existentes en el sector rural regional: altiplano, valles altos o precordilleranos y valles bajos y oasis. Estos sectores geográficos determinan distintas especializaciones productivas agropecuarias, diferentes conexiones con la sociedad regional y procesos lingüísticos divergentes. Los resultados concernientes al total de pueblos indígenas y regiones comprendidos pueden verse en: Gundermann, Vergara et al. (2005). 
Tabla II. Declaraciones de competencia en lengua indígena por parte de personas que se autoadscriben como aymaras, según sector geográfico.

\begin{tabular}{|l|rr|rr|rr|c|}
\hline Sector geográfico & \multicolumn{2}{|c|}{$\begin{array}{c}\text { Con } \\
\text { competencia }\end{array}$} & \multicolumn{2}{c|}{$\begin{array}{c}\text { Sin } \\
\text { competencia }\end{array}$} & Total & $\begin{array}{c}\text { Auto- } \\
\text { adscripción } \\
\text { aymara }\end{array}$ \\
\hline Altiplano & 59 & $95,2 \%$ & 3 & $4,8 \%$ & 62 & $34,3 \%$ & $89,9 \%$ \\
\hline Precordillera & 38 & $61,2 \%$ & 24 & $38,7 \%$ & 62 & $34,3 \%$ & $58,5 \%$ \\
\hline Valles bajos, oasis y pampa & 22 & $38,6 \%$ & 35 & $61,4 \%$ & 57 & $31,5 \%$ & $25,3 \%$ \\
\hline Total & 119 & $65,7 \%$ & 62 & $34,3 \%$ & 181 & $100 \%$ & $44,9 \%$ \\
\hline
\end{tabular}

Fuente: Encuesta Contexto Sociolingüístico de Comunidades Escolares Indígenas, 2003.

Las proporciones encontradas son representativas de la situación de vigencia del aymara en las comunas estudiadas ya que la muestra es proporcional a la población de dichas comunas. Luego, por tratarse de zonas con una prolongada e ininterrumpida residencia indígena y en donde se reconoce una mayor permanencia de la cultura y la lengua aymaras, (regiones de Arica - Parinacota y Tarapacá) es en ellas donde podemos encontrar los más altos porcentajes relativos de hablantes ${ }^{45}$.

Un grupo amplio de los que declaran competencia en lengua aymara señala un buen desempeño en el castellano $(87,2 \%)$, mientras que los casos con baja solvencia representan sólo un 12,8\% (asimilables a un bilingüismo en que el castellano está en posición subordinada). Esta alta competencia se contrapone visiblemente con el 48,5\% de competencia baja que se declara para el aymara. En el mismo sentido, el amplio dominio del castellano contrasta con la mucho menor proporción $(30,9 \%)$ de personas que aseguran tener un manejo comparable en jaqi aru. Lo indicado se confirma y acentúa si se considera que, aproximadamente, un tercio del total de quienes se identifican como aymaras son monolingües del castellano, mientras que habría desaparecido completamente el monolingüismo aymara. Casos de bilingüismo aymara-castellano entre niños y escolares se presentan sólo en los sectores geográficos más altos, como el altiplano. Estamos entonces en presencia de contextos sociales en que dicho bilingüismo está presente en poco más de un tercio del total de los casos (un 35,5\%); o sea, donde prevalece claramente el monolingüismo castellano.

Entre aquellos que declaran competencia en lengua aymara se da una situación bastante heterogénea respecto al aprendizaje de la primera lengua, que puede ser el castellano, el aymara o las dos lenguas a la vez. La mayor parte (un 44,8\%) ha

${ }^{45}$ Dado que los centros urbanos concentran la mayor parte de la población indígena regional -los aymaras urbanos alcanzan a un 78,5\% según el último censo (INE - Orígenes, 2005)-, pudiera ser que allí haya una mayor cantidad de hablantes, pero seguramente una menor proporción de hablantes competentes. 
aprendido simultáneamente ambas lenguas; un 31,3\% aprendió primero castellano y después aymara; la situación inversa (aprendizaje del aymara y luego del castellano) sólo se presenta en un 23,9\% de los casos y corresponde, principalmente, a adultos mayores. Siguiendo la tendencia a la permanencia de la lengua en los sectores ubicados a mayor altitud, el mayor número de personas que declaran tener al aymara como primera lengua reside en el altiplano (83,9\%), porcentaje que también incluye a quienes lo aprenden simultáneamente con el castellano. Lo inverso ocurre en las zonas bajas. Tal situación es indicativa de un rápido proceso de reemplazo por el castellano, que está aprendiéndose de manera temprana y masiva en todos los hogares indígenas de la zona rural de la región. En la práctica, ya no se presenta el caso de que se estén comunicando primero en aymara y más tarde en castellano. A diferencia de lo señalado por Grebe (1986) hace dos décadas y Salas (1996), los resultados del estudio señalan que el aymara, cuando llega a adquirirse, lo hace junto o con posterioridad al castellano.

Salvo excepciones, la lengua andina no es objeto de un esfuerzo consciente de enseñanza - aprendizaje equivalente al del castellano, más bien al contrario: los padres voluntaria o involuntariamente tienden a limitar su empleo y, por hábito o decisión, se comunican en castellano con sus hijos y otras personas de la localidad. El aymara se adquiere únicamente si constituye un medio de comunicación usual en la red social inmediata: pertenencia a familias con hablantes activos, vivir o estar en contacto continuo con localidades altoandinas donde históricamente dicha lengua ha sufrido una menor presión del castellano, o por tener posibilidades de interacción frecuente con adultos mayores que la emplean regularmente en el hogar y localidad. La intervención de los padres y otros miembros del hogar es determinante: la gran mayoría de los encuestados que domina el aymara lo aprendió de sus padres. La red parental y la localidad pueden tener una influencia favorable para la mantención y, eventualmente, la ampliación de los conocimientos lingüísticos, pero es indispensable la acción de la familia, donde se aprende realmente la lengua.

En sentido inverso, las emigraciones andinas, su redistribución en la región y el aumento de la residencia urbana producen una fragmentación de las redes familiares y de crianza de los niños. La familia nuclear se encuentra con frecuencia fuera de las localidades rurales, en tanto las formas de agrupación familiar más amplias ahora están residencialmente dispersas en la región. Mientras los adultos mayores, aymara hablantes, residen, en un importante número, en las comunidades, la mayor parte de los niños y jóvenes estudia y vive en sectores urbanos, salvo durante los breves periodos del año en que pueden retornar a sus comunidades de origen. Por ende, dejan de presentarse o disminuyen las condiciones favorables para el uso del aymara y, sobre todo, su aprendizaje por las nuevas generaciones. Como consecuencia, el castellano domina hoy ampliamente en las interacciones sociales dentro del hogar, las redes familiares y la localidad de residencia. 
Los antecedentes presentados ponen en evidencia una situación crítica de la lengua aymara. Este diagnóstico puede ser confirmado considerando las condiciones y características del uso de la lengua indígena y del castellano. En concordancia con lo ya visto, la lengua originaria se emplea poco y, además, presenta segmentaciones internas que conllevan un uso del aymara socialmente diferenciado. En efecto, al interior de los pueblos de precordillera, valles bajos y oasis existe una notoria distancia social entre los inmigrantes con mayor dominio del aymara y los residentes originarios sin competencia en esta lengua. Estos agregados de personas suelen interactuar intensamente, pero lo hacen en castellano, la lengua conocida por todos y claramente prevaleciente en la comunicación. El empleo del aymara, en tanto, se circunscribe a los espacios de interacción entre los inmigrantes, únicos que pueden hablarlo. Cuando estos interlocutores están más dispersos, como en los pueblos del desierto o en las ciudades de la costa, el uso del aymara se limita al hogar (si existen internamente las condiciones y hábitos para ello), o a instancias comunicativas con integrantes de redes parentales y de la comunidad de origen. En el altiplano y la frontera con Bolivia, en cambio, se emplea en una variedad de interacciones, no obstante que el peso del castellano también se hace sentir por su condición de lengua de dominio común y en las relaciones externas con agentes escolares o autoridades.

El uso del aymara adquiere así una fisonomía característica: en las comunas altoandinas tiende a darse una concordancia entre agregados sociales y lingüísticos; en las zonas de precordillera, valles bajos y oasis del desierto, en cambio, se produce una segmentación étnica y social entre quienes han emigrado desde el altiplano y tienen competencia en aymara y quienes son oriundos de estos sectores y ya no lo comprenden ni lo hablan. Hay una frontera simbólica y lingüística entre los dos grupos que define y refuerza estereotipos sociales ${ }^{46}$. Los "originarios" identifican a los inmigrantes como un grupo distinto, a los que a veces aplican denominaciones devaluadoras: "paisanos" o "indios". En el mismo acto niegan para sí mismos dicha condición de indígenas y, con ello, la asociación con la lengua aymara. Pese a esto, en los últimos años se ha producido en este grupo un fenómeno de identificación étnica (especialmente inducido por agencias estatales como CONADI) que, aparentemente, no ha eliminado, pero sí disminuido la distancia social con el otro sector, lo que podría conllevar un cambio de actitud favorable hacia la lengua aymara.

El empleo del aymara se organizaría entonces según dos principios: la menor o mayor amplitud del círculo de interacción social y el carácter intra o extraétni-

${ }^{46} \mathrm{Al}$ respecto, afirman Gumpertz y Bennett (1981: 133): "Los juicios de los hablantes sobre el significado social y cognitivo de determinadas diferencias lingüísticas concretas tienden a reflejar estereotipos antes que hechos concretos. El resultado de esto es que la existencia misma de diferencias entre sistemas lingüísticos, sean éstos códigos o estilos, se convierte en vehículo de transmisión y mantenimiento de los estereotipos sociales". 
co del mismo. Puede esperarse que la lengua vernácula se hable mayormente en interacciones sociales entre indígenas y personas socialmente cercanas; o sea, ámbitos intraétnicos y socialmente restringidos. A la inversa, su uso disminuye exponencialmente a medida que nos introducimos en espacios de relación interétnica y/o donde confluyen un mayor número de participantes que no guardan entre sí relaciones familiares o de 'comunalidad' y en que resulta común la presencia de monolingües del castellano. Así, mientras mayor cercanía se dé en la interacción comunicativa, más plausible es que los actores involucrados opten por el aymara. Por el contrario, mientras más público y externo sea el ambiente, habrá una mayor utilización del castellano ${ }^{47}$.

\section{CONCLUSIONES: ETAPAS EN EL BILINGÜISMO Y CONSECUEN- CIAS DE DESPLAZAMIENTO}

En los párrafos siguientes intentaremos organizar los análisis precedentes en las etapas que ha seguido el bilingüismo jaqi aru - castellano durante los dos últimos siglos, su distribución sobre el espacio regional y los efectos, caso de haberlos, en el desplazamiento de la lengua originaria.

Un momento inicial es el que cabe denominar como de monolingüismo aymara generalizado. Salvando casos especiales (indígenas criados desde niños con sacerdotes o familias criollas), todos los "indios" de la región aprenden el jaqi aru y se comunican sólo en esta lengua. Así lo testifica un observador atento como Bollaert. Los aymaras todavía constituyen en la Región de Arica y Tarapacá la gran mayoría de la población. El sistema de dominación se caracteriza por relaciones neocoloniales establecidas por el régimen peruano de tierras y tributación indígenas, lo que representa una continuación modificada de las relaciones coloniales previas y, también, por la permanencia de gobiernos locales indígenas. Los nexos fiscales (relación con autoridades) y económicos (trabajo asalariado, mercado de productos campesinos) ocupaban "lenguaraces" cuando era necesario. Todo ello hasta la década de 1850, momento en que se abren paso, con el término de la tributación de indígenas, cambios sociales y culturales de gran profundidad, los lingüísticos entre otros.

Durante las últimas décadas del siglo XIX y las primeras del siglo XX se materializan transformaciones económicas y sociales en las regiones de Tarapacá y Tacna-Arica, adquiriendo éstas una estructuración moderna. Son responsables de ello las industrias extractivas, principalmente la del salitre, el circuito mercantil que vincula el puerto de Arica con el norte de Bolivia que, desde 1913, evolucio-

${ }^{47}$ Los resultados que acabamos de resumir son en lo general convergentes con los del estudio de González, S. (1990). 
na en una red ferroviaria, unido a la minería de altura que esta última posibilita (azufre, bórax, en menor medida cobre) y el desarrollo urbano asociado (puertos, pueblos y campamentos mineros). La región andina y sus habitantes se vinculan a estos ciclos económicos proveyendo fuerza de trabajo (obreros, arrieros), productos campesinos (forrajes, frutas y verduras, granos, carne) y demandando bienes de consumo industriales. Los imperativos de comunicación obligan a aprender la lengua general. Ello se lleva a efecto de manera informal y espontánea en las relaciones sociales con castellano hablantes y de modo formal a partir del momento en que algunas localidades andinas importantes cuentan con escuelas primarias fiscales, particulares y parroquiales ${ }^{48}$. Asimismo, a principios del siglo XX se da inicio a la conscripción militar y, con ello, a la alfabetización en lengua castellana cuando se requirió. Es un periodo de expansión del bilingüismo en la precordillera andina $y$ persistencia del monolingüismo en el altiplano (hasta 1930, aproximadamente).

Las siguientes generaciones de bilingües se conformaron no sólo a través de medios externos como los indicados, sino que en primer lugar por la temprana enseñanza del castellano que se lleva a efecto en los hogares y familias. Cuando el bilingüismo se generaliza, y si lo anterior se acompaña -como de hecho se diodel desprestigio del jaqi aru y de la condición sociocultural de "indio" a la que se asocia, el monolingüismo castellano empieza a expandirse. En algunas áreas esto ocurre antes que en otras. En general, desde los principales centros poblados de la precordillera andina (Pica, Mamiña, Tarapacá, Camiña, Codpa, Belén y Putre) se expande el castellano más temprano que en los valles y poblados precordilleranos situados en el corazón de la cordillera y aislados. A su vez, el progreso de la castellanización en la precordillera andina de Tarapacá se habría dado antes que las áreas septentrionales (Arica y Parinacota). Las regiones ganaderas de la alta cordillera permanecerán todavía monolingües por varias décadas.

Le sigue un monolingüismo castellano en la precordillera andina y expansión del bilingüismo en el altiplano (hasta inicios de la década de 1970, aproximadamente). La interrupción de la transmisión del aymara en las aldeas agrícolas de la precordillera tiene un impacto decisivo sobre la suerte de los hablantes del jaqi aru. No obstante, ello está lejos de ser algo homogéneo, tanto por el arribo de algunas personas y familias desde zonas aymarófonas (Bolivia, comunidades ganaderas del altiplano, aldeas agrícolas altas con hablantes), como por la persistencia de la lengua en algunos sitios; por ejemplo, los poblados de la quebrada de Aroma (Chiapa, Sotoca, Jaiña), o Chapiquiña, que contaban todavía con hablantes hasta hace unos años. La heterogeneidad a veces se da al interior de una misma localidad donde algunas personas nativas del lugar permanecen bilingües en un medio que se hace

${ }^{48}$ Luis Castro ha enfatizado la debilidad de la acción escolar en el área andina durante el ciclo expansivo de la industria del salitre en Tarapacá. Según su parecer, que también es el nuestro, ello cambia considerablemente a partir de la década de 1930 (Castro, 2004: 57-68). 
cada vez más monolingüe del castellano ${ }^{49}$.

La crisis salitrera y la brusca disminución de la población en los campamentos salitreros liberan escuelas que se reubican en las aldeas precordilleranas. Ello se materializa durante las décadas de 1930 y 1940, años en que se completa la red escolar. En paralelo, mejora la red de caminos para vehículos motorizados y la circulación de personas y cargas hacia y desde los sectores andinos. Este pulso de integración encuentra una población bilingüe que, por su influjo, se hace monolingüe del español, relegando el bilingüismo a las personas mayores. A medida que pasan los años y que los interlocutores y ámbitos sociales para el uso del aymara se enrarecen, la lengua deja de transmitirse y su empleo languidece.

En la alta cordillera, en cambio, la lengua originaria permanece vital. No obstante, las continuas relaciones que con fines de intercambio y trabajo se mantienen con las áreas agrícolas de una precordillera (o valles bajos como Lluta) que se va haciendo monolingüe del castellano obligan a la adquisición de esta última lengua. El trabajo minero en algunas oficinas salitreras o en la explotación del azufre de Tacora conduce al mismo resultado. Por lo demás, ya en la década de 1940 se da inicio a experiencias autogestionadas de alfabetización y castellanización con el concurso de profesores. Por ejemplo, en Cariquima e Isluga.

En la década de 1950 se establece la red escolar en el altiplano, la que se va completando en las dos siguientes. Se universaliza así la alfabetización y la castellanización aymara. En la de 1960 se desarrolla la red de caminos que conecta el altiplano con la precordillera ${ }^{50} \mathrm{y}$ con las ciudades de la costa (también algunos valles aislados, como las aldeas de la quebrada de Aroma), lo que multiplica las posibilidades de movilidad hacia zonas bajas en que el castellano prevalece ampliamente (precordillera) o es la única lengua conocida (centros urbanos). Campañas de alfabetización son realizadas en las décadas de 1950, 1960 y 1970 con el concurso de profesores primarios; carabineros de las dotaciones de frontera también hacen lo suyo. La conscripción militar y la alfabetización que la acompaña contribuyen a ampliar el dominio del castellano entre los hombres jóvenes del altiplano.

$\mathrm{Al}$ menos dos pulsos de integración con consecuencias lingüísticas se advierten entonces para el periodo que examinamos. Primero, el que se apoya en la red escolar y la conectividad vial de la precordillera, entre otros factores, desde 1930 hasta 1950, con consecuencias de ampliación del monolingüismo castellano e inicios del bilingüismo en el altiplano. Segundo, el que se da con la extensión del sistema escolar y la integración física y económica del altiplano en las décadas de 1950,

${ }^{49}$ Juan Carlos Mamani muestra el caso de algunas ancianas de Socoroma, en la precordillera de la comuna de Putre, nativas del lugar y bilingües hasta ahora, mientras que la absoluta mayoría de sus coetáneos y convecinos son monolingües del castellano (Mamani, J.C., 2005: 176-191).

${ }^{50} \mathrm{La}$ red de caminos en el altiplano norte es anterior a la de la alta cordillera de Tarapacá. No obstante, ella conectaba con el ferrocarril de Arica a la Paz y no con la precordillera y Arica. Esto se resuelve en la década indicada. 
1960 y 1970 y, con ello, la generalización del bilingüismo, antesala de un monolingüismo ya consolidado en la precordillera andina.

Desde la primera mitad de la década de 1970, aproximadamente, se abre una etapa de bilingüismo en retroceso y de progresión del desplazamiento del jaqi aru. Las emigraciones desde la zona andina a los valles bajos, los pueblos del desierto y las ciudades costeras son notorias en la década de 1950 (en particular, desde la precordillera) y se intensifican en la de 1960 y 1970, ahora con el concurso del altiplano. En efecto, se inauguran las emigraciones desde allí a las zonas agrícolas y desde ellas hacia los valles de Arica y las ciudades de la costa, las que algo más adelante también se hacen directas. La consecuencia sociolingüística más importante es que la lengua aymara se redistribuye por toda la región, a tenor de los desplazamientos de sus hablantes; el jaqi aru se regionaliza por tanto. Se asiste de esta manera a un movimiento inverso al que históricamente había vivido la lengua desde la segunda mitad del siglo XIX: no se retrae hacia la alta cordillera andina, sino que se dispersa en la región. La mayoría de sus poseedores se transforma en residentes urbanos.

Sin embargo, ello tiene lugar en momentos en que el bilingüismo se ha generalizado entre quienes mantenían la lengua vernácula y cuando en las cohortes escolares más jóvenes se expande el monolingüismo castellano. Estos hablantes encuentran en la precordillera, en los valles, los pueblos y las ciudades costeras ambientes lingüísticos completamente dominados por la lengua oficial. El empleo de la lengua propia queda limitado entonces a las redes sociales de paisanos y a los espacios de interacción y sociabilidad aymaras remanentes, pero sin que en la mayoría de ellos alcance exclusividad.

Finalmente, una etapa de bilingüismo y educación intercultural bilingüe (desde 1993). Conviene quizás destacar como algo particular este periodo que se abre a partir de la promulgación de la Ley Indígena $\mathrm{N}^{\circ} 19.253$, que promueve un ambiente más favorable para el libre empleo de las lenguas vernáculas, allí donde previamente no se las toleraba con facilidad o simplemente se las reprimía. También porque con ese mismo instrumento legal se sientan las bases para la puesta en práctica de un Programa de Educación Intercultural Bilingüe (EIB) en comunidades escolares, principalmente rurales, de la región aymara.

El balance entrega notas dulces y amargas. Es indudable que en el norte del país hoy se vive una mucha mayor distensión en cuanto a la expresión pública de la lengua y cultura indígenas. Nos parece estar en presencia de una más definida inscripción de sus expresiones en un registro de significaciones étnicas, y ya menos en uno que las ubicaba en la pertenencia cultural boliviana o peruana, o en el atraso y la carencia de civilización, como fue común en el pasado. Lentamente se abre paso en algunos sectores de la comunidad regional que lo aymara (personas, lengua y cultura) integran una arquitectura social regional plural no confundible simplemente con lo extranjero. Sin embargo, el monolingüismo castellano sigue 
ampliándose con rapidez, a pesar de los cambios en las sensibilidades culturales internas y externas. $\mathrm{Al}$ respecto, las acciones que desde la educación formal (Programa de EIB) se han implementado no tendrían un efecto de contra marcha respecto de la lengua ${ }^{51} y$, posiblemente, tampoco de la cultura ${ }^{52}$, a pesar de que las valoraciones sociales están cambiando. La Educación Intercultural Bilingüe (EIB) tendría efectos sociolingüísticos, pero ellos no son precisamente los de ampliar la base de hablantes, avanzar en competencia o en vitalidad lingüística; antes bien, lo que se alcanza es identificación cultural y étnica con apoyo, entre otras cosas, en el uso de la lengua como símbolo estratégico de etnicidad.

¿Está echada la suerte del jaqi aru? La desaparición de la lengua aymara en Chile no representa una necesidad histórica o sociológica y, de llegar a producirse, tendrán que pasar todavía varias décadas. Por lo demás, difícilmente ello puede llegar a ser completo, en tanto se mantenga la presión migratoria aymara desde Bolivia, donde dicha lengua conserva una mayor vitalidad y está ampliamente extendida en su uso y aprendizaje. Lo más preocupante hoy nos parece el hecho de que los vectores de desplazamiento lingüístico no se han modificado. Muy visiblemente, las representaciones acerca de cultura y lengua originarias han adquirido valoraciones positivas para la mayoría de quienes se autodeclaran aymaras, dando un vuelco respecto de lo que ocurría un par de décadas atrás, pero de ello no se derivan, hasta ahora, prácticas lingüísticas que generen una inflexión en el retroceso y desplazamiento de su lengua.

\section{REFERENCIAS}

Acevedo, M.I., R. Gálvez y Raab M. 1970. Los migrantes de los pueblos del interior del departamento de Arica y su asimilación al contexto de la ciudad de Arica. Santiago: Escuela de Sociología, Universidad de Chile.

Archivo Nacional (AN), Archivo Judicial de Iquique (JI), Legajo 1157.

Archivo de la Intendencia de Tarapacá (AIT), Varios (Vol. 28, 1912); Establecimientos educacionales (S/Vol., 1945 y Vol. 4, 1953/1954)

Barceló, L. 1924. "Appendix to the counter-case of the Republic of Chile". Documentos presentados por el Estado chileno al árbitro norteamericano, s/i. Santiago: Gobierno de Chile.

Bermúdez, O. 1963. Historia del salitre, tomo I: Desde sus Origenes hasta la Guerra del Pacifico. Santiago: Ediciones de la Universidad de Chile.

\footnotetext{
${ }^{51}$ La introducción de la lengua vernácula en el aula es muy limitada en contenidos por parte de docentes que, en su gran mayoría, tampoco dominan la lengua.

${ }^{52}$ Hablamos de los repertorios culturales aymaras. Lo que se acompaña de una notoria proliferación y mayor heterogeneidad de repertorios culturales no tradicionales de los que son portadores hoy los aymaras.
} 
Bermúdez, O. 1975. "Esbozo biográfico de William Bollaert", en Norte Grande I (3-4), pp. 313-318.

Bermúdez, O. 1981. Historia del salitre, tomo II: Desde la Guerra del Pacifico hasta la Revolución de 1891. Santiago: Ediciones Pampa Desnuda.

Bollaert, W. 1860. Antiquarian, ethnological and other researches in New Granada, Equador, Peru and Chile whit observations of the Pre-Incarial, Incarial, and other Monuments of Peruvian Nations. Londres: Trübner \& Co.

Bollaert, W. 1975. "Descripción de la provincia de Tarapacá", en Norte Grande I (3), pp. 459-479.

Bravo-Elizondo, P. y González, S. 1994. Iquique y la pampa. Relaciones de corsarios, viajeros e investigadores (1500-1930). Iquique: Taller de Estudios Regionales (TER) - Universidad José Santos Ossa.

Cajías, F. 1975. La Provincia de Atacama, 1825-1842. La Paz: Instituto Boliviano de Cultura.

Castro, L. 2004. "Una escuela fiscal ausente, una chilenización inexistente: la precaria escolaridad de los aymaras de Tarapacá durante el ciclo expansivo del salitre (1880-1920), Cuadernos Interculturales 2 (3), pp. 57-68.

Castro, L. 2008. "El estado chileno, los agentes fiscales y el temprano ordenamiento administrativo del espacio andino de la provincia de Tarapacá (18801930)", en Chungara 40 (2), pp. 219-233.

Díaz, A. 2006. Chilenización y comunidad andina. Escuela, reclutamiento militar y articulaciones en Putre, 1883-1929. San Pedro de Atacama: Tesis de Maestría en Antropología, Programa de Postgrado en Antropología UCN-UTA.

Díaz, A. 2009. "Los andes de bronce. Conscripción militar de comuneros andinos y el surgimiento de las bandas de bronce en el norte de Chile", en Historia 42 (2), pp. 371-399.

Díaz, A. y Ruz. R. 2009a. "Comuneros andinos en la administración chilena (Arica, 1880 - 1929)", en Revista de Historia Social y de las Mentalidades 13 (2), Universidad de Santiago.

Díaz, A. y Ruz R. 2009b. "Estado, escuela chilena y población andina en la ex Subdelegación de Putre. Acciones y reacciones durante el periodo de post Guerra del Pacífico (1883-1929)", en Polis 8 (24), pp. 311-340.

Durán, T. y Ramos, N. 1986. "Incorporación del español por los mapuches del centro - sur de Chile durante los siglos XVI, XVII y XVIII", en Lenguas Modernas 13, pp. 17-36.

Durán, T. y Ramos, N. 1987a. "Incorporación del español por los mapuches del centro-sur de Chile durante el siglo XIX", en Lenguas Modernas 14, pp. 179196.

Durán, T. y Ramos, N. 1987b. "El problema del contacto sociolingüístico temprano entre mapuches y españoles", en Actas de Lengua y Literatura Mapuche, 8-10 octubre de 1986, Temuco, pp. 173-184. 
Espinoza, E. 1903. Jeografía descriptiva de la República de Chile. Santiago: Imprenta Barcelona, 5 a edición.

Fasold, R. 1996. La sociolingüistica de la sociedad. Madrid: Visor Libros.

Fishman, J. 1988. Sociología del lenguaje. Madrid: Cátedra.

García, P. 1997. Aru pirwa. Breve diccionario: español-aymara, aymara-español. Iquique: Ediciones Instituto de Estudios Andinos, Universidad Arturo Prat (UNAP).

Gavira, C. 2005. "Producción de plata en el mineral de San Agustín de Huantajaya (Chile), 1750-1804", en Chungará 37 (1), pp. 37-57.

González, H. 1996a. Características de la migración campo ciudad entre los aymaras del norte de Chile. Arica: Corporación Norte Grande, Serie Documentos de Trabajo.

González, H. 1996b. Las agrupaciones de migrantes aymara urbanos en el norte de Chile: adaptación a la ciudad y vínculos con las comunidades de origen. Arica: Corporación Norte Grande, Serie Documentos de Trabajo.

González, H. 1997a. "Economía y uso del espacio en la sociedad aymara actual". En Actas Segundo Congreso Chileno de Antropología. Santiago: Colegio de Antropólogos, pp. 567-579.

González, H. 1997b. "La inserción económica de los migrantes aymaras en la ciudad: el trabajo como empresa familiar y la reproducción cultural". En Actas Segundo Congreso Chileno de Antropología. Santiago: Colegio de Antropólogos, 315-324.

González, H. 2009. Características de la migración aymara en Chile. Ponencia al seminario Internacional Pueblos Indígenas y Migración, Arica (MS).

González, S. 1990. El aymara de la Provincia de Iquique - Chile y la educación nacional. Iquique: Taller de Estudios Regionales (TER), Cuadernos de Educación Intercultural No 1.

González, S. 2002a [1990]. Hombres y mujeres de la pampa: Tarapacá en el ciclo de expansión del salitre. Santiago: Eds. LOM- Dirección de Bibliotecas, Archivos y Museos (DIBAM) -UNAP, 2da. Ed. ampliada y corregida.

González, S. 2002b. Chilenizando a Tunupa. La escuela pública en el Tarapacá andino, 1880-1990. Santiago: DIBAM-UNAP.

González, S. 2009. "La presencia boliviana en la sociedad del salitre y la nueva definición de la frontera: auge y caída de una dinámica transfronteriza (Tarapacá 1880-1930)", en Chungara 41 (1), pp. 71-81.

González, Y. 2007. "Servicio militar obligatorio y disciplinamiento cultural: aproximaciones al caso mapuche-huilliche en el siglo XX”, en Alpha 24, Universidad de Los Lagos, Osorno, pp. 111-137.

Gootenberg, P. 1991. "Population and ethnicity in early republican Peru: some revisions", en Latin American Research Review 26 (3), pp. 109-157.

Grebe, M. E. 1986. "Cambio sociolingüístico y bilingüismo aymara español en 
Isluga”, en Lenguas Modernas 13, pp. 7-53.

Gumpertz, J. y Bennett, A. 1981. Lenguaje y cultura. Barcelona: Editorial Anagrama.

Gundermann, H. 1987. Antecedentes sociolingüisticas de la lengua aymara en la provincia de Parinacota, Informe de Investigación inédito, Arica, Chile: Universidad de Tarapacá.

Gundermann, H. 2001. Comunidad, sociedad andina y procesos sociohistóricos en el norte de Chile. Tesis Doctoral, Centro de Estudios Sociológicos, El Colegio de México.

Gundermann, H. 2007. "Pueblos indígenas en la región atacameña moderna”, en Historia Indigena 10, pp. 63-87.

Gundermann, H.; Vergara, J.I. et al. 2005. Descripción del contexto sociolingüistico en comunidades indígenas de Chile. Santiago de Chile: Programa de Educación Intercultural Bilingüe (PEIB), Ministerio de Educación.

Gundermann, H. y González, H. 2008. "Pautas de integración regional, migración, movilidad y redes sociales en los pueblos indígenas de Chile", en Universum, Revista de Humanidades y Ciencias Sociales 3 (1), pp. 81-114.

Hidalgo, J. 1984. "Descomposición cultural de Atacama en el siglo XVIII: lenguas, escuelas, fugas y complementariedad ecológica”, en Bittman, B. (Coord.) Simposio Culturas Atacameñas. 44 Congreso Internacional de Americanistas Antofagasta: Universidad del Norte, pp. 221-249.

Instituto Nacional de Estadísticas (INE). 2003. Censo 2002, sintesis de resultados. Santiago de Chile.

Instituto Nacional de Estadísticas (INE) - Programa Orígenes. 2005. Estadísticas sociales de los pueblos indigenas de Chile, INE, Santiago.

Kasbarian, J. M. 1997. "Langue minorée et langue minoritaire", en Moureau, M.L. (Ed.), Sociolinguistique, concepts de base. Pierre Mardaga, Francia.

Keller, C. 1946. El Departamento de Arica. Censo Económico Nacional, vol. 1, Santiago: Ministerio de Economía y Comercio.

Kessel, J. V. 1980. Holocausto al progreso. Los aymarás de Tarapacá. Amsterdam: CEDLA.

Kubler, G. 1952. The Indian Caste of Peru, 1796-1940: A population Study Based upon Tax Records and Census Reports. Washington D.C: Smithsonian Institution, Institute of Social Anthropology Publications $N^{\circ} 14$.

Lambert, W. 1977. "The effects of bilingualism on the individual: cognitive and sociocultural consequences". En Hornby, A. P. (Ed.) Bilingualism: Psychological, Social and Educational Implications. Nueva York: Academic Press, pp. 71-85.

Lenz, R. 1905-1910. Diccionario etimológico de las voces chilenas derivadas de lenguas indigenas americanas. Santiago: Imprenta Cervantes.

Mamani, J. C. 2005. Los rostros del aymara en Chile: el caso de Parinacota. La Paz: 
PINSEIB/PROEIB-Andes / Plural Editores.

Mamani, M. 1985. Bilingüismo y su problemática educacional en la Provincia de Parinacota, Arica: Universidad de Tarapacá, Documento de Trabajo.

Marx, Karl. 1972 [1857-1858]. "Introducción”. Elementos fundamentales para la crítica de la economía politica, Vol. 1. Santiago: Siglo XXI Argentina Editores Editorial Universitaria, pp. 3-33.

Palacios, R. 1974. La chilenización de Tacna y Arica, 1883-1929. Lima: Editorial Arica.

Phillippi, R. A. 1860. Viage al desierto de Atacama hecho de orden del gobierno de Chile en el verano 1853-54. Halle, Sajonia: Librería de E. Anton.

Salas, Adalberto. 1996. "Lenguas indígenas de Chile". En Hidalgo y Virgilio Schiappacasse et. al. (eds.), Etnografia, pp. 257-295. Santiago de Chile: Editorial Andrés Bello.

Sánchez, Gilberto. 1993-94. "Estado actual de las lenguas aborígenes de Chile", en Boletin de la Academia Chilena de la Lengua 71. [En línea]. Disponible en http://www.uchile.cl/facultades/csociales/lenguajes/estadolg.htm. Consulta: 01/03/2011.

Thompson, I. y Angerstein, D. 1997. Historia del ferrocarril en Chile. Santiago: DIBAM, Centro Barros Arana.

Villalobos, S. 1979. La economía de un desierto. Tarapacá durante la Colonia. Santiago: Universidad Católica de Chile, Ediciones Nueva Universidad. 